\section{D) Check for updates}

Cite this: Dalton Trans., 2020, 49, 12662

\title{
Ambidentate bonding and electrochemical implications of pincer-type pyridylidene amide ligands in complexes of nickel, cobalt and zinc $\uparrow$
}

\begin{abstract}
Philipp Melle, Nathalie Ségaud (D) and Martin Albrecht (D) *
Pincer-type tridentate pyridyl bis(pyridylidene amide) ( pyPYA $_{2}$ ) ligand systems were coordinated to the Earth-abundant first row transition metals nickel, cobalt and zinc. A one-pot synthesis in water/ethanol afforded octahedral homoleptic bis-PYA complexes, $\left[M(\text { pyPYA })_{2}\right]\left(P F_{6}\right)_{2}$, whereas five-coordinate monoPYA dichloride complexes, $\left[M\left(\right.\right.$ pyPY $\left.\left.A_{2}\right) \mathrm{Cl}_{2}\right]$, were obtained upon slow addition of the ligand to the metal chlorides in DMF. Electrochemical measurements further revealed a facile oxidation of the metal centers from $\mathrm{Ni}^{2+}$ to $\mathrm{Ni}^{4+}$ and $\mathrm{Co}^{2+}$ to $\mathrm{Co}^{3+}$, respectively, while the $\mathrm{Zn}^{2+}$ system was redox inactive. These experiments further allowed for quantification of the much stronger electron donor properties of neutral $N, N, N$-tridentate pyPYA 2 pincer ligands as compared to terpy. Remarkably, ortho-PYA pincer ligands feature amide coordination to the metal center via oxygen or nitrogen. This ambidentate ligand binding constitutes another mode of donor flexibility of the PYA ligand system, complementing the resonance structure dynamics established previously. NMR spectroscopic and MS analysis reveal that the meta-PYA ligand undergoes selective deuteration when coordinated to cobalt. This reactivity suggests the potential of this ligand as a transient proton reservoir for $\mathrm{HX}$ bond activation and, moreover, indicates the relevance of several resonance structures and therefore supports the notion that meta-PYA ligands are mesoionic.
\end{abstract}

Received 14th July 2020,

Accepted 21st August 2020

DOI: $10.1039 / \mathrm{d} 0 \mathrm{dt} 02482 \mathrm{a}$

rsc.li/dalton ment of highly efficient hydrogenation catalysts that are competitive with the best ruthenium catalysts. ${ }^{16}$ Likewise manganese(I) pincer complexes have been explored as attractive alternative to established ruthenium- and iridium-based catalysts in (de)hydrogenation as well as in $\mathrm{C}-\mathrm{C}$ and $\mathrm{C}-\mathrm{X}$ bondforming reactions. ${ }^{17}$ Also nickel complexes have gained much attention recently, e.g. as low-cost replacement for palladium in cross-coupling reactions. ${ }^{18}$

We have recently developed a new pincer platform based on pyridylidene amide (PYA) ligands (A, Fig. 1), which imparted high catalytic activity to ruthenium centers in transfer hydrogenation catalysis. ${ }^{19,20}$ Based on the relatively hard yet formally neutral amide donor site of these PYA ligands, we sought to expand the application of this ligand system towards first row transition metals in view of providing a more sustainable alternative to noble metals. PYA ligands have been shown to induce attractive catalytic properties to iridium, ruthenium ${ }^{21-26}$ and palladium ${ }^{27}$ complexes, in parts by stabilizing high-valent oxidation states and in other parts due to their unique electron donor flexibility. ${ }^{28-30}$ Despite these attractive features, no first row transition metal complexes with PYA ligands have been reported, but analogous pyridylidene amine (PYE) ligands have been coordinated to nickel centers by the groups of Johnson ${ }^{31}$ and Douthwaite ${ }^{32}$ (B and C, Fig. 1). Here we report nickel, cobalt, and zinc complexes con-
Department für Chemie und Biochemie, Universität Bern, Freiestrasse 3 ,

CH-3012 Bern, Switzerland.E-mail: martin.albrecht@dcb.unibe.ch

$\dagger$ Electronic supplementary information (ESI) available: Crystallographic details, IR and NMR spectra, electrochemical analyses, synthetic details for the Ru complex. CCDC 2015875-2015883. For ESI and crystallographic data in CIF or other electronic format see DOI: $10.1039 /$ dodt02482a 


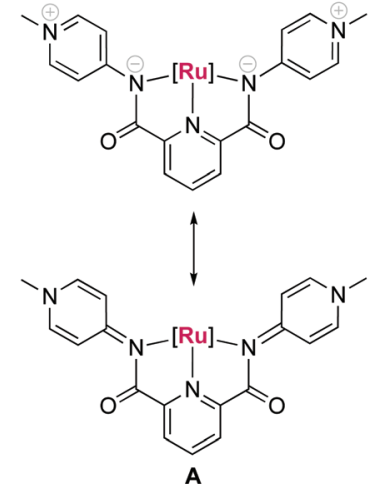

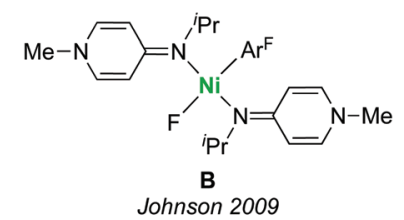

Fig. 1 Pincer pyridylidene amide (PYA) ruthenium complex A with two limiting PYA resonance structures, and pyridylidene amine (PYE) nickel complexes $\mathbf{B}$ and $\mathbf{C}$ reported earlier.

taining the pyridyl bis(PYA) ( pyPYA $_{2}$ ) pincer ligand and disclose some unique reactivity properties, including the linkage isomerism between $\mathrm{N}$ - to $\mathrm{O}$-coordination of the PYA ligand as well as isotope exchange reactions at the meta-PYA unit that support a mesoionic notion of this ligand.

\section{Results and discussion}

\section{Synthesis and characterization of bis(PYA-pincer) complexes}

The known para- and meta-pyPYA 2 ligand precursor salts 1a and $\mathbf{1 b}$ were prepared according to standard procedures. ${ }^{19,33}$
Similarly, the ortho-pyPYA 2 ligand precursor 1c was prepared from 2-aminopyridine and 2,6-pyridinedicarbonyl dichloride followed by selective methylation of both aminopyridine sites and anion metathesis. Notably, methylation required an excess of MeOTf (5 eq.) to be quantitative, while the use of MeI, which was sufficient for methylation of the para and meta analogues, resulted in only partial methylation. Complexation to cobalt and nickel was accomplished by reacting the dicationic ligand salts $1 \mathrm{a}-\mathbf{c}$ with the corresponding chloride salt $\left(\mathrm{CoCl}_{2}\right.$, $\mathrm{NiCl}_{2}$ ) in the presence of $\mathrm{Na}_{2} \mathrm{CO}_{3}$ as a base (Scheme 1). Complexation under these conditions consistently afforded the octahedral homoleptic complexes $\left[\mathrm{M}\left(\mathrm{pyPYA}_{2}\right)_{2}\right]\left(\mathrm{PF}_{6}\right)_{2}(\mathrm{M}=\mathrm{Co}$, 2a-c; $\mathbf{M}=\mathrm{Ni}, \mathbf{3 a - c}$ ) even when a large excess of the metal salt was used. This reactivity pattern contrasts the analogous ruthenation, which exclusively afforded mono-ligated $\left[\mathrm{Ru}\left(\right.\right.$ pyPYA $\left._{2}\right)$ $\left.(\mathrm{MeCN})_{3}\right]^{2+}$ complexes. Complexes 2 and $\mathbf{3}$ are paramagnetic and NMR silent, their quantitative elemental composition, structure and purity was therefore confirmed by CHN microanalysis, single crystal X-ray diffraction, and HR ESI-MS. The latter showed the monocationic complex fragments $\left[\mathrm{M}-\mathrm{PF}_{6}\right]^{+}$, e.g. at 898.1733 amu for 2a (calcd 898.1733).

Crystallographic analysis revealed ambidentate coordination of the ortho-pyPYA 2 ligand in $2 \mathbf{c}$ and $3 \mathbf{c}$, as one of the ligands is bound to the metal center in the typical $\kappa^{3}-N, N, N$ bonding mode, while the other ligand binds with the amide through oxygen in a $\kappa^{3}-O, N, O$ coordination mode ( $c f$. Scheme 1, Table S1, Fig. S1 $\dagger$ ). Both meta-pyPYA 2 ligands in complexes $\mathbf{2 b}$ and $\mathbf{3 b}$ show the expected $\kappa^{3}-N, N, N$ coordination through the amide nitrogens and the central pyridine as observed for related dianionic pyridine dicarboxamidate

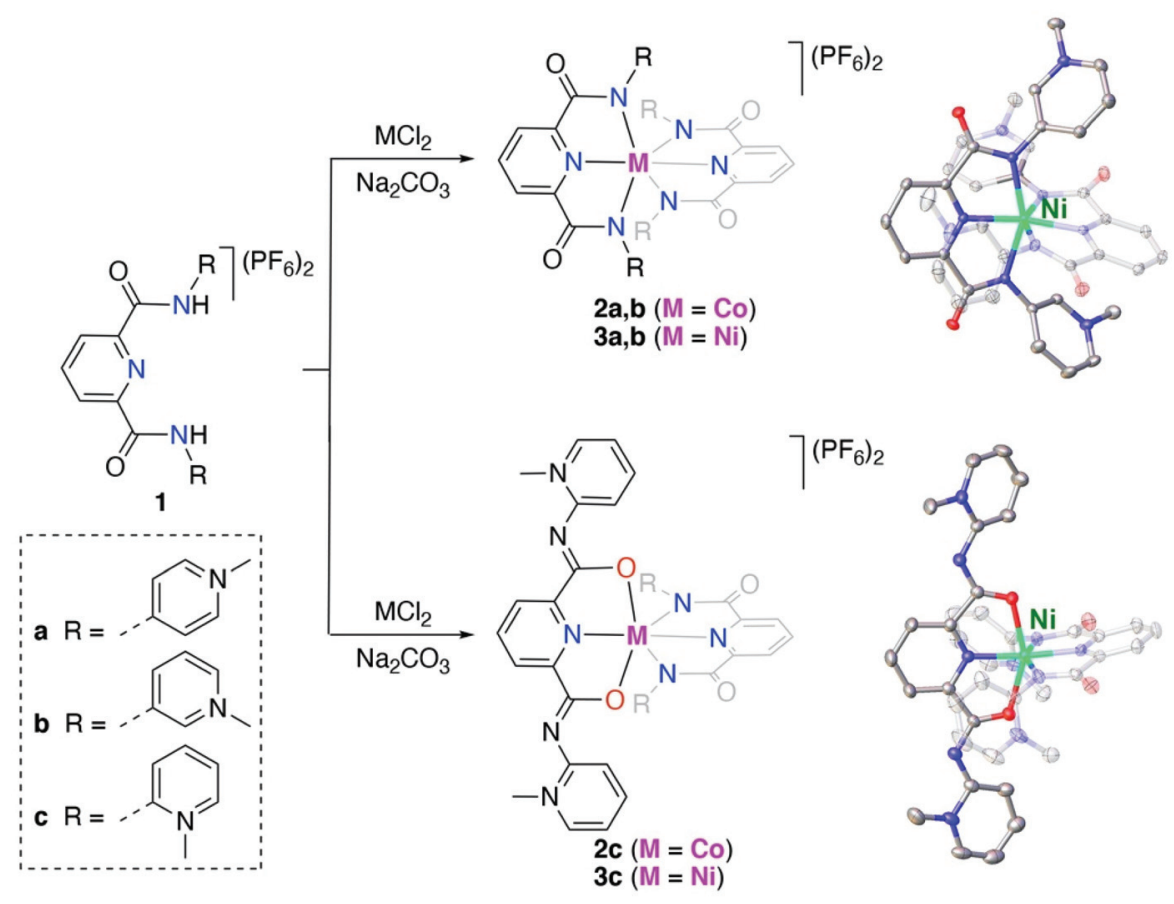

Scheme 1 Synthesis of $\mathrm{Co}(I)$ and $\mathrm{Ni}(॥)$ bis-pyPYA 2 pincer complexes $2 \mathrm{a}-\mathrm{c}$ and $3 \mathrm{a}-\mathrm{c}$ in $\mathrm{H}_{2} \mathrm{O} / \mathrm{EtOH}(1: 1 \mathrm{v} / \mathrm{v})$. Crystal structures of complex cations $3 \mathrm{~b}$ and $3 \mathrm{c}$; all ellipsoids at 50\% probability level (hydrogen atoms and co-crystallized solvent molecules omitted for clarity). 
systems. ${ }^{34-36}$ Such a linkage isomerism of PYA ligands has been proposed, ${ }^{37}$ yet never established so far $^{38}$ and presents a further type of flexibility of the PYA system. Notably, the same ortho-pyPYA 2 ligand displayed the classic $\kappa^{3}-N, N, N$-coordination mode when bound to ruthenium(II) in $[\mathrm{Ru}$ (orthopyPYA 2$\left.)(\mathrm{MeCN})_{3}\right]\left(\mathrm{PF}_{6}\right)_{2}$ (Fig. S2 $\dagger$ ). Likewise, pyridine dicarboxamide systems with ortho-dimethylated aryl substituents show exclusively $\kappa^{3}-N, N, N$-bonding. ${ }^{35,39}$ The $\kappa^{3}-O, N, O$ coordination mode is unprecedented and presumably a consequence of the Lewis acidity of the first row transition metal centers and their ensuing oxophilicity, combined with the unique donor flexi-

Scheme 2 Synthesis of $\mathrm{Ni}(॥)$ and $\mathrm{Co}(॥)\left[\mathrm{M}\left(\mathrm{pyPYA}_{2}\right) \mathrm{Cl}_{2}\right]$ complexes $4 \mathrm{a}-\mathrm{c}$ and $5 \mathrm{a}-\mathrm{c}$ by slow addition of deprotonated ligand at room temperature. bility of the formally neutral and sterically constrained orthoPYA donor site, and distinguishes these ligands from the more commonly used pyridine carboxamide systems.

\section{Synthesis and characterization of mono(PYA-pincer) complexes}

The synthesis of cobalt and nickel mono-PYA complexes, $\left[\mathrm{M}\left(\right.\right.$ pyPYA $\left.\left._{2}\right) \mathrm{Cl}_{2}\right]$ complexes $\mathbf{4 a}-\mathbf{c}(\mathrm{M}=\mathrm{Co})$ and $\mathbf{5 a}-\mathbf{c}(\mathrm{M}=\mathrm{Ni}$; Scheme 2), was accomplished by slow addition of a filtered DMF solution containing the ligand and $\mathrm{Na}_{2} \mathrm{CO}_{3}$ to a DMF solution containing the metal chloride. The slow addition of ligand as well as the choice of solvent played a crucial role. Initial attempts to control the reaction of the PYA ligands 1a-c with $\mathrm{MCl}_{2}$ by quenching the reaction at early reaction times or by using a large excess of the metal salt (up to 10 eq.) invariably resulted in the formation of the homoleptic $\left[\mathrm{M}\left(\text { pyPYA }_{2}\right)_{2}\right]^{2+}$ compounds 2 and 3 .

Formation of complexes 4 and $\mathbf{5}$ was established by $\mathrm{CHN}$ microanalysis as well as HR ESI-MS, which showed the monocationic complex fragments $[\mathrm{M}-\mathrm{Cl}]^{+}$, e.g. at $441.0409 \mathrm{amu}$ for 4a (calcd 441.0403). The set of cobalt complexes $4 \mathbf{a}-\mathbf{c}$ was furthermore characterized by single crystal X-ray diffraction analysis (Fig. 2). The complexes feature a strongly distorted trigonal bipyramidal arrangement $\left(\tau_{5}=0.45-0.49\right),{ }^{40}$ which is in good agreement with the reported analogous structure of $\left[\mathrm{Co}(\right.$ terpy $\left.) \mathrm{Cl}_{2}\right]$ (terpy = terpyridine). ${ }^{41}$ The para- and meta-PYA pincer ligands in complexes $\mathbf{4 a}, \mathbf{b}$ bind to the metal center in a $\kappa^{3}-N, N, N$ coordination mode whereas the ortho-PYA pincer ligand in $4 \mathbf{c}$ is again $\kappa^{3}-O, N, O$ coordinated as observed for the bis-PYA pincer complexes. Notably, steric constraints should be less relevant when the PYA pincer ligand is bound to the $\mathrm{CoCl}_{2}$ fragment than in bis-PYA pincer complexes, indicating an electronic stabilization of the PYA coordination through oxygen.

The para- and meta-PYA pincer ligands in complexes $\mathbf{4 a , b}$ are almost planar, i.e. the dihedral angle between the PYA heterocycles and central pyridine ring are only $8.5^{\circ}, 9.8^{\circ}$ in $4 a$ and

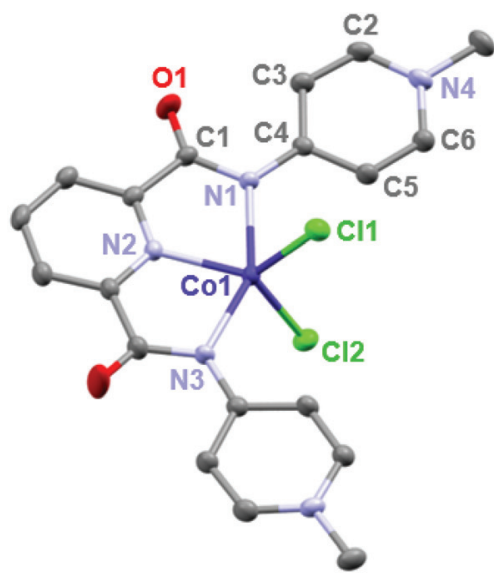

$4 a$

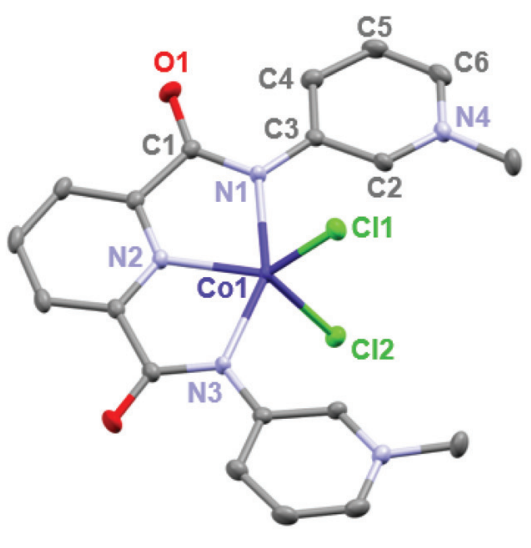

$4 b$

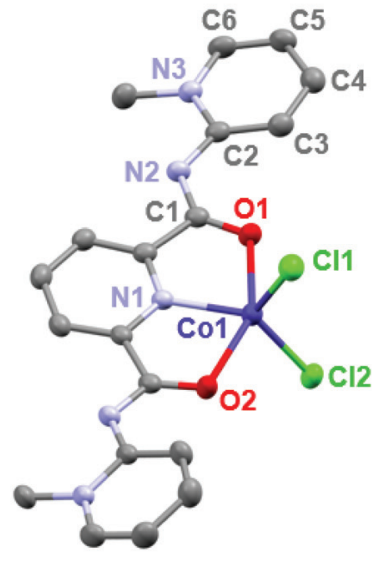

$4 c$

Fig. 2 ORTEP representations of mono-pyPYA 2 cobalt complexes $4 a-c$; all ellipsoids at 50\% probability level (hydrogen atoms and co-crystallized solvent molecules omitted for clarity). 
Table 1 Selected bond lengths $(\AA)$ and angles $\left({ }^{\circ}\right)$ of mono-pyPYA $A_{2}$ complex cations $4 a-c$

\begin{tabular}{|c|c|c|c|c|}
\hline & $4 a$ & $4 \mathrm{~b}$ & & $4 c$ \\
\hline Co1-N1 & $2.227(2)$ & $2.185(1)$ & Co1-O1 & $2.217(2)$ \\
\hline Co1-N2 & $2.020(2)$ & $2.005(1)$ & Co1-N1 & $2.018(1)$ \\
\hline Co1-N3 & $2.217(2)$ & $2.185(1)$ & $\mathrm{Co} 1-\mathrm{O} 2$ & $2.225(2)$ \\
\hline Co1-Cl1 & $2.315(1)$ & $2.330(1)$ & Co1-Cl1 & $2.249(1)$ \\
\hline $\mathrm{Co} 1-\mathrm{Cl} 2$ & $2.296(1)$ & $2.330(1)$ & $\mathrm{Co} 1-\mathrm{Cl} 2$ & $2.262(1)$ \\
\hline $\mathrm{N} 1-\mathrm{C} 1^{a}$ & $1.360(3)$ & $1.347(2)$ & $\mathrm{N} 2-\mathrm{C}^{a}{ }^{a}$ & $1.331(3)$ \\
\hline $\mathrm{C} 1-\mathrm{O}^{a}{ }^{a}$ & $1.231(2)$ & $1.244(2)$ & $\mathrm{C} 1-\mathrm{O} 1^{a}$ & $1.254(2)$ \\
\hline $\mathrm{N} 1-\mathrm{C} 3 / 4^{a}$ & $1.373(2)$ & $1.391(2)$ & $\mathrm{N} 2-\mathrm{C} 2^{a}$ & $1.353(3)$ \\
\hline $\mathrm{C} 3-\mathrm{C}^{a}{ }^{a}$ & $1.412(3)$ & $1.406(2)$ & $\mathrm{C} 2-\mathrm{C} 3^{a}$ & $1.405(3)$ \\
\hline $\mathrm{C} 4-\mathrm{C} 5^{a}$ & $1.419(3)$ & $1.388(2)$ & $\mathrm{C} 3-\mathrm{C} 4^{a}$ & $1.368(4)$ \\
\hline $\mathrm{C} 5-\mathrm{C} 6^{a}$ & $1.364(3)$ & $1.366(2)$ & $\mathrm{C} 4-\mathrm{C} 5^{a}$ & $1.393(4)$ \\
\hline $\mathrm{C} 6-\mathrm{N} 4^{a}$ & $1.345(3)$ & $1.349(2)$ & $\mathrm{C} 5-\mathrm{C}^{a}{ }^{a}$ & $1.353(3)$ \\
\hline $\mathrm{N} 4-\mathrm{C} 2^{a}$ & $1.353(2)$ & $1.342(2)$ & $\mathrm{C} 6-\mathrm{N} 3^{a}$ & $1.356(3)$ \\
\hline $\mathrm{C} 2-\mathrm{C} 3^{a}$ & $1.365(3)$ & $1.399(2)$ & $\mathrm{N} 3-\mathrm{C} 2^{a}$ & $1.375(3)$ \\
\hline N1-Co1-N3 & 153.1(1) & 154.1(1) & $\mathrm{O} 1-\mathrm{C} 01-\mathrm{O} 2$ & $152.0(2)$ \\
\hline$\theta$ PYA-pyr ${ }^{b}$ & $8.5 \& 9.8$ & $10.4 \& 10.4$ & $\theta$ PYA-pyr ${ }^{b}$ & $11.3 \& 25.8$ \\
\hline$\tau_{5}^{c}{ }^{c}$ & 0.46 & 0.49 & $\tau_{5}^{c}$ & 0.45 \\
\hline
\end{tabular}

${ }^{a}$ Average of two bonds. ${ }^{b}$ Dihedral angle $\theta$ between the PYA heterocycles and the pyridyl-amide plane. ${ }^{c}$ See ref. 40.

$10.4^{\circ}$ in $\mathbf{4 b}$ respectively (Table 1 ), which is distinctly different when compared to the correspondent homoleptic complex variation $\left[\mathrm{Co}(\text { meta-pyPYA })_{2}\right]\left(\mathrm{PF}_{6}\right)_{2}$ which show a $55^{\circ}$ twist between the PYA and central pyridyl planes. This high planarity may hint to a significant $\pi$-contribution of the $N_{\text {amide }}-C_{P Y A}$ bonds (N1-C3/4) in both complexes. In such a model, the amide nitrogen is acting predominantly as neutral L-type $\mathrm{N}$-donor ligand, presumably as a consequence of the higher electron density at the formally neutral metal center in complexes $\mathbf{4}$ and $\mathbf{5}$ compared to the dicationic center in the bis (pincer) complexes 2 and 3 . In agreement with a more pronounced L-type and $\pi$-acidic binding mode of the amide nitrogen, the para-PYA heterocycles of complex 4 a reveal a pronounced diene-imine resonance form with localized double and single bonds (average C2-C3 and C5-C6 1.365(4) A, average C3-C4 and C4-C5 bonds (1.415(7) A; Table 1). This bond alteration implies considerable contribution of the imine resonance structure of the PYA unit ( $c f$. bottom structure of $\mathbf{A}$ in Fig. 1).

The $\kappa^{3}-O, N, O$ coordination mode of the ortho-PYA pincer ligand in mono-pyPYA ${ }_{2}$ complex $4 \mathbf{c}$ suggests this complex to be an intermediate en route to the formation of the heteroleptic bis-pyPYA 2 pincer complex 2c. The stronger coordination of the $O, N, O$ donor set may then accommodate a second PYA pincer ligand in the more typical $\kappa^{3}-N, N, N$ mode.

\section{Dynamic linkage isomerism of the ortho-PYA-pincer ligand system}

For better spectroscopic analysis in solution, the analogous zinc(II) complexes $\left[\mathrm{Zn}\left(\mathrm{pyPYA}_{2}\right)_{2}\right]\left(\mathrm{PF}_{6}\right)_{2} \mathbf{6 a}-\mathbf{c}$ were prepared by reacting ligands $1 \mathrm{a}-\mathrm{c}$ with 0.5 eq. $\mathrm{ZnCl}_{2}$ under mildly basic conditions (Scheme 3). In contrast to the paramagnetic and NMR-silent octahedral $\mathrm{Co}$ (II) and Ni(II) complexes 2 and 3, complexes 6a-c are diamagnetic and allow for NMR spectroscopic characterization. Ligand coordination to the $\mathrm{Zn}^{\mathrm{II}}$ center resulted in the loss of the $\mathrm{NH}$ amide proton resonances and in a marked upfield shift of the aromatic $\mathrm{H}_{\text {PYA }}$ proton resonances, e.g. from $\delta_{\mathrm{H}}=9.76\left(\mathrm{H}_{\text {PYA }}^{6}\right)$ in meta-PYA ligand $1 \mathbf{b}$ to $\delta=$ 8.43 in complex $\mathbf{6 b}$.

All zinc complexes $\mathbf{6 a - c}$ feature one distinct set of PYA ligand proton resonances, including $\mathrm{N}^{-\mathrm{CH}_{3}}\left(\delta_{\mathrm{H}}\right.$ around 4$)$, pyridyl $\left(\delta_{\mathrm{H}} 8.25-8.70\right)$ and pyridylidene $\left(\delta_{\mathrm{H}} 7.08-8.43\right)$ signals. This symmetric arrangement indicates that both pyPYA ligands in each zinc complex are coordinated in the same mode, most presumably the typical $\kappa^{3}-N, N, N$-coordination based on the structures of the cobalt and nickel analogues and previously described structures. ${ }^{19,42-45}$

The symmetric ligand bonding in $6 \mathrm{c}$ containing orthopyPYA $_{2}$ ligands contrasts the solid state bonding established for the analogous nickel and cobalt complexes $2 \mathrm{c}$ and $3 \mathrm{c}$ comprised of a mixture of $\kappa^{3}-N, N, N$ and $\kappa^{3}-O, N, O$ pincer coordination. NMR spectroscopic analysis of complex $\mathbf{6 c}$ at low temperature indicated decoalescence of the signals into two sets in a 9:1 integral ratio, indicating the presence of two species (Fig. 3). Based on the six inequivalent aromatic resonances, the major species was assigned to the homoleptic bis- $\kappa^{3}-N, N, N$ coordinated pincer isomer. The minor isomer features at least ten inequivalent proton signals, which were therefore attributed to mixed $\kappa^{3}-N, N, N / \kappa^{3}-O, N, O$-coordination isomer ( $c f$. structures of $2 \mathbf{c}, 3 \mathbf{c}$ ). These measurements therefore suggest that at room temperature, complex $\mathbf{6 c}$ undergoes rapid $\kappa \mathrm{N}-/ \kappa \mathrm{O}$-amide isomerization.

The dynamic process of this complex was investigated by variable temperature ${ }^{1} \mathrm{H}$ NMR spectroscopic experiments in $\mathrm{CD}_{2} \mathrm{Cl}_{2}$ in the +20 to $-80{ }^{\circ} \mathrm{C}$ temperature range (Fig. $\mathrm{S} 3 \dagger$ ). Decoalescence of most of the pyridyl and PYA proton resonances was observed around $-40{ }^{\circ} \mathrm{C}$, apart from the PYA $\mathrm{H}^{6}$

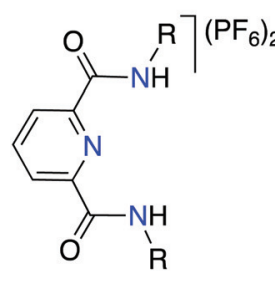

1

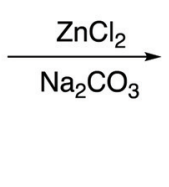

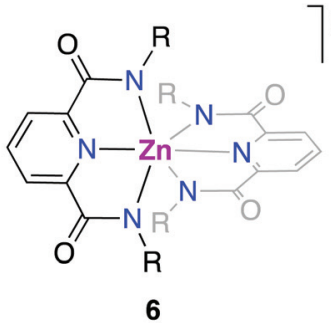

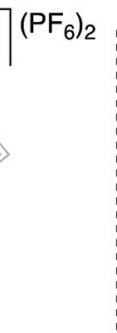

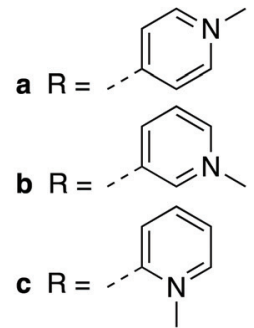

Scheme 3 Synthesis of $\left.\left[\mathrm{Zn}(\text { pyPYA })_{2}\right)_{2}\right]\left(\mathrm{PF}_{6}\right)_{2}$ complexes $6 a-c$. (a) 0.5 eq. $\mathrm{ZnCl}_{2} ; 3$ eq. $\mathrm{Na}_{2} \mathrm{CO}_{3}$ in $\mathrm{MeCN}$. 


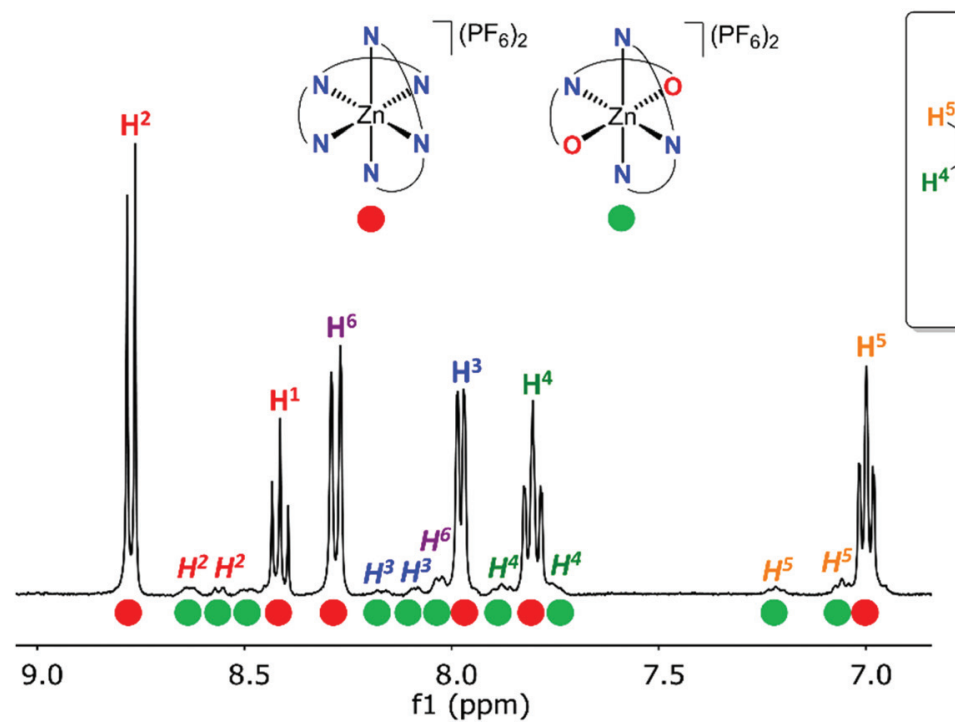

Fig. $3{ }^{1} \mathrm{H}$ NMR spectrum of $\left[\mathrm{Zn}(\text { ortho-pyPYA })_{2}\right]\left(\mathrm{PF}_{6}\right)_{2} 6 \mathrm{c}$ in $\mathrm{CD}_{2} \mathrm{Cl}_{2}$ at $-80{ }^{\circ} \mathrm{C}$, revealing two different complexes in $9: 1$ ratio. The major species was assigned to the bis- $\left(\kappa^{3}-N, N, N\right)$-coordination isomer (red circles), the minor species to the mixed $\kappa^{3}-N, N, N / \kappa^{3}-O, N, O$-coordination isomer (green circles).

signal, which undergoes the largest shift and features a coalescence temperature $T_{\mathrm{c}}$ around $-20{ }^{\circ} \mathrm{C}$. Based on these values and applying the Eyring equation, an average activation energy $\Delta G^{\ddagger}=11.4 \pm 0.3 \mathrm{kcal} \mathrm{mol}^{-1}$ was calculated for this PYA linkage isomerism (Table $\mathrm{S} 2 \dagger$ ). ${ }^{46,47} \mathrm{~A}$ similar behavior was noted in $\mathrm{CD}_{3} \mathrm{CN}$ (Fig. $\mathrm{S} 4 \dagger$ ), though due to the higher melting point of this solvent, the decoalescence was not resolved. Nonetheless, these experiments suggest that the dynamic bonding is not significantly depending on the solvent.

The bonding mode in the bis-( pyPYA $\left._{2}\right)$ complexes was further analyzed by solid state infrared (IR) spectroscopy of the pure compounds. The ligand precursor 1a features three characteristic absorption bands for the amide carbonyl and PYA-imine units in the $1580-1700 \mathrm{~cm}^{-1}$ region (Table 2, Fig. S5-S11 $\dagger$ ). ${ }^{48}$ Upon metalation, the two lower bands around 1590 and $1645 \mathrm{~cm}^{-1}$ remain essentially unchanged, while the high energy band at $1706 \mathrm{~cm}^{-1}$ shifts characteristically to 1617 $( \pm 1) \mathrm{cm}^{-1}$, presumably due to metal coordination to the amide unit (Fig. 4a). Likewise, the strong absorption above $1700 \mathrm{~cm}^{-1}$ for ligand precursors $\mathbf{1 b}$ and $\mathbf{1 c}$ shifts to lower energy upon metalation, though assignments are more complicated as all bands shift considerably (Fig. 4b and Fig. S5 $\dagger$ ). It is worth noting that the shift is independent of the metal center and that the IR spectra are essentially identical for Co(II), Ni(II), and $\mathrm{Zn}$ (II) complexes for the para- and meta-pyPYA ${ }_{2}$ ligand even in the low frequency area. This high similarity suggests an identical coordination mode for all three metal complexes. For the ortho-pyPYA ${ }_{2}$ series, however, subtle differences are noted in the $1550-1650 \mathrm{~cm}^{-1}$ range which distinguish the $\mathrm{Zn}$ from the Ni and Co systems (Fig. 4c). These differences may point to a different ligand behavior, which may be associated with the $\kappa^{3}-N, N, N$ vs. $\kappa^{3}-O, N, O$ linkage isomerism established

Table 2 Characteristic IR stretch frequencies of all compounds in the carbonyl/imine range between $1580-1700 \mathrm{~cm}^{-1}$ and redox potentials of all compounds

\begin{tabular}{|c|c|c|c|c|c|c|}
\hline$\frac{\text { Entry }}{1}$ & $\frac{\text { Ligand motif }}{\text { para-PYA }}$ & \multicolumn{2}{|c|}{ Bonding partner } & $\frac{\nu_{\mathrm{C}=\mathrm{O} / \mathrm{C}=\mathrm{N}}\left[\mathrm{cm}^{-1}\right]}{1593,1646,1706}$ & $\frac{E_{1 / 2}\left(\mathrm{M}^{\mathrm{II} / \mathrm{III}}\right)^{a}[\mathrm{~V}]}{-}$ & $\frac{E_{1 / 2}\left(\mathrm{M}^{\mathrm{III} / \mathrm{IV}}\right)^{a}[\mathrm{~V}]}{-}$ \\
\hline 2 & para-PYA & Co & $2 a$ & $1586,1617,1642$ & $0.20(90)$ & - \\
\hline 5 & meta-PYA & $\mathrm{H}$ & $1 \mathrm{~b}$ & 1695 & - & - \\
\hline 6 & meta-PYA & Co & $2 b$ & 1567 & $0.01(80)$ & - \\
\hline 7 & meta-PYA & $\mathrm{Ni}$ & $3 \mathbf{b}$ & 1564 & $1.03(80)$ & $1.54(90)$ \\
\hline 10 & ortho-PYA & Co & $2 c$ & 1597,1628 & 0.40 (100) & - \\
\hline 11 & ortho-PYA & $\mathrm{Ni}$ & $3 c$ & 1598,1627 & $1.34(100)$ & - \\
\hline 12 & ortho-PYA & $\mathrm{Zn}$ & $6 c$ & 1587,1630 & - & - \\
\hline
\end{tabular}

${ }^{a}$ Potentials in MeCN $v$ s. SSCE at $100 \mathrm{mV} \mathrm{s}^{-1}$ scan rate using the $\mathrm{Fc}^{+} / \mathrm{Fc}$ couple as standard; $E_{1 / 2}=+0.43 \mathrm{~V}$ and $\left(n \mathrm{Bu}_{4} \mathrm{~N}\right) \mathrm{PF}_{6}$ as electrolyte, $0-2.2 \mathrm{~V}$ sweep range; $\Delta E_{\mathrm{p}}=\left|E_{\mathrm{pc}}-E_{\mathrm{pa}}\right|[\mathrm{mV}]$ in parenthesis. 
a)

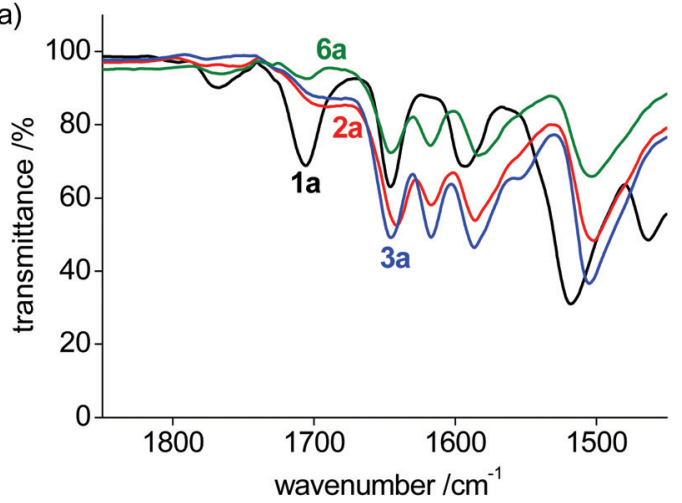

b)

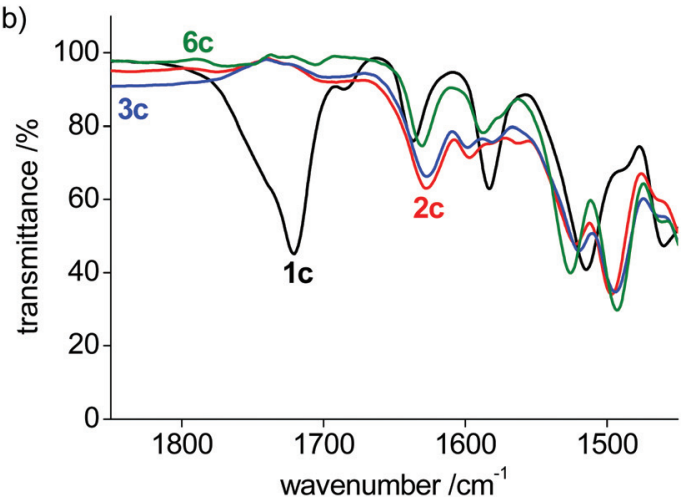

Fig. 4 IR spectra of (a) para-pyPYA 2 pincer complex series; (b) ortho-pyPYA 2 pincer complex series.

for the $\left[\mathrm{Zn}(\text { ortho-pyPYA })_{2}\right]\left(\mathrm{PF}_{6}\right)_{2}$ complex $6 \mathbf{c}$ by NMR spectroscopy. IR spectroscopy therefore does not conclusively indicate whether this linkage isomerism is exclusively occurring at $\mathrm{Zn}^{2+}$, or whether it is more general for ortho-pyPYA ligands and also takes place at $\mathrm{Co}^{2+}$ and $\mathrm{Ni}^{2+}$. The exclusive $\kappa^{3}-O, N, O$ bonding in the solid state of the latter two complexes ( $c f$. structures of $\mathbf{2 c - 5 c}$ ) might be induced by lower solubility or a preferential crystal packing of the mixed coordination isomer, leading to a dynamic kinetic resolution of the two isomers through crystallization.

\section{Redox properties of homoleptic bis-PYA pincer complexes}

The orange meta-pyPYA $\mathrm{P}_{2}$ cobalt(II) complex $2 \mathbf{b}$ oxidized to the green $\mathrm{Co}(\mathrm{III})$ analogue $2 \mathbf{b}^{+}$under aerobic conditions in a saturated aqueous solution (Scheme 4). The oxidation state of the cobalt center in $\mathbf{2} \mathbf{b}^{+}$was unambiguously identified by crystallographic analysis due to the $0.2 \AA$ shorter $\mathrm{Co}-\mathrm{N}$ bond distances compared to $\mathbf{2 b}$ as well as the presence of three $\mathrm{PF}_{6}{ }^{-}$counter ions. This oxidation under mild conditions indicates strong donor properties of the PYA pincer ligand in these cobalt and nickel complexes. Therefore, the electrochemical properties of the complexes were investigated by cyclic voltammetry.

Cobalt complexes $\mathbf{2 a - c}$ show reversible redox processes in the 0 to $+0.5 \mathrm{~V}$ potential range that were assigned to metal-centered $\mathrm{Co}^{2+}$ to $\mathrm{Co}^{3+}$ oxidations (all potentials vs. Ag/AgCl; Fig. 5). The octahedral complex [Co(terpy $\left.)_{2}\right]\left(\mathrm{PF}_{6}\right)_{2}{ }^{49}$ was also included to compare the donor strength of the formally neutral triden- tate PYA pincer ligands with a well-studied reference compound. The reversibility of the $\mathrm{M}^{\mathrm{II} / \mathrm{III}}$ oxidation processes in complexes 2 and 3 is supported by the linear relationship of anodic $\left(I_{\mathrm{pa}}\right)$ and cathodic peak currents $\left(I_{\mathrm{pc}}\right) v s$. the square root of the scan rate (Fig. S12 $\dagger$ ). This linearity together with the small peak potential difference $\Delta E_{\mathrm{p}}<105 \mathrm{mV}$ (Table 2) indicates a diffusion limited electron transfer process. ${ }^{50-52}$ The oxidation potential is dependent on the PYA substitution pattern and is lowest for cobalt coordinated to the meta-PYA pincer ligand $\left(E_{1 / 2}=0.01 \mathrm{~V}\right.$ in $\left.2 \mathbf{b}\right)$ and increases with para-PYA $\left(E_{1 / 2}=\right.$ $0.20 \mathrm{~V}$ in $2 \mathrm{a})^{53}$ and even more with ortho-PYA pincer ligands $\left(E_{1 / 2}=0.40 \mathrm{~V}\right.$ in $\left.2 \mathrm{c}\right)$. It is noteworthy that $\left[\mathrm{Co}(\text { ortho-pyPYA })_{2}\right]$ $\left(\mathrm{PF}_{6}\right)_{2}$ complex $2 \mathrm{c}$ features two consecutive redox processes in the potential range of $0.3-0.6 \mathrm{~V}$, which might be caused by possible linkage isomerism in solution and the presence of two coordination isomers (exclusively $\kappa^{3}-N, N, N$-coordinated ligand and mixed coordination mode, $c f$. NMR studies of analogous ortho-PYA zinc complex above). These half wave potentials indicate an increase of ligand donor strength along the series ortho-PYA < para-PYA < meta-PYA, a trend that has been previously observed for $\left[\mathrm{Ru}\left(\mathrm{pyPYA}_{2}\right) \mathrm{L}_{3}\right]^{2+}$ and $\left[\operatorname{IrCp}{ }^{*}\right.$ (phenylPYA)L $]^{+}$complexes. ${ }^{19,54}$ This trend points to a strongly $\pi$-basic character of the meta-PYA donor, while the donor properties of the ortho-PYA unit are probably attenuated by the vicinity of the formally positively charged pyridinium nitrogen. When compared to the redox properties of $\left[\mathrm{Co}(\text { terpy })_{2}\right]^{2+}\left(E_{1 / 2}=0.32\right.$ $\mathrm{V})^{55}$ the ortho-PYA pincer ligand is less donating than terpy,
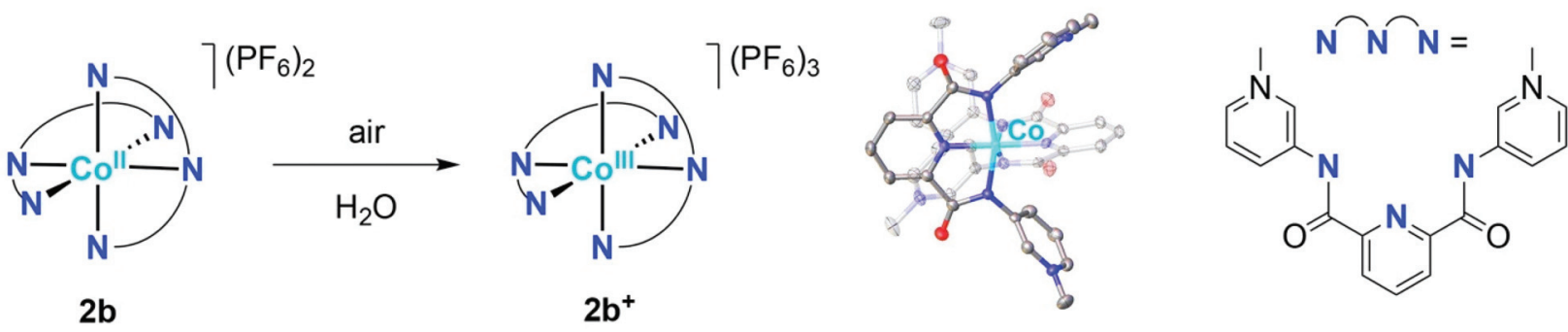

Scheme 4 Oxidation of $\left[\mathrm{Co}(\text { meta-pyPYA })_{2}\right]\left(\mathrm{PF}_{6}\right)_{2} \mathbf{2 b}$ in $\mathrm{H}_{2} \mathrm{O}$ under aerobic conditions, to the Co(III) complex $2 \mathrm{~b}^{+}$. Crystal structure of complex cation $2 \mathrm{~b}^{+}$; all ellipsoids at $50 \%$ probability level (hydrogen atoms and co-crystallized solvent molecules omitted for clarity). 

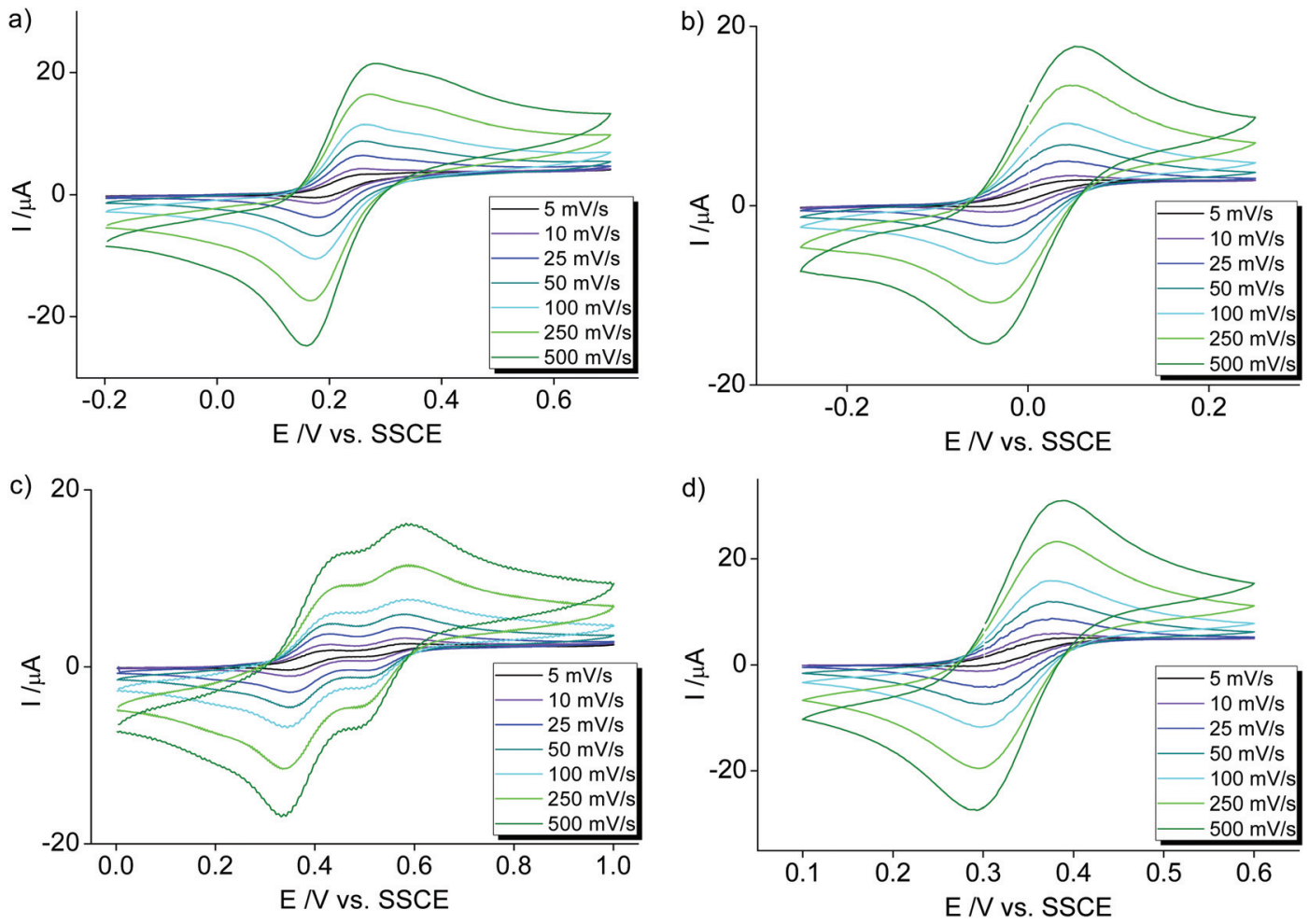

Fig. 5 Cyclic voltammetry measurements of homoleptic $\left[\mathrm{Co}\left(\mathrm{pyPYA}_{2}\right)_{2}\right]\left(\mathrm{PF}_{6}\right)_{2}$ complexes in $\mathrm{MeCN}$ : (a) 2a $\left[\mathrm{Co}(\text { para-pyPYA })_{2}\right]\left(\mathrm{PF}_{6}\right)_{2} ;(\mathrm{b}) 2 \mathrm{2b}[\mathrm{Co}($ metapyPYA $\left.\left.)_{2}\right)_{2}\right]\left(\mathrm{PF}_{6}\right)_{2} ;$ (c) $\left.2 \mathrm{c}\left[\mathrm{Co}(\text { ortho-pyPYA })_{2}\right)_{2}\right]\left(\mathrm{PF}_{6}\right)_{2} ;$ (d) $\left[\mathrm{Co}(\text { terpy })_{2}\right]\left(\mathrm{PF}_{6}\right)_{2}$. Conditions: $10 \mathrm{~mL}$ solvent, $1 \mathrm{mM}$ sample and $100 \mathrm{mM}\left(n \mathrm{nu}_{4} \mathrm{~N}\right) \mathrm{PF}_{6}$ as supporting electrolyte at 5-500 $\mathrm{mV} \mathrm{s}^{-1}$ scan rate (potentials vs. $\mathrm{Ag} / \mathrm{AgCl}$ using the $\mathrm{Fc}^{+} / \mathrm{Fc}$ couple as standard; $E_{1 / 2}=+0.4319$ ).

while the para and even more so the meta analogue are stronger donors.

The metal-centered nature of the oxidation process was confirmed by redox analyses of the $\mathrm{Zn}$ analogues $\mathbf{6 a - c}$. These complexes do not show any redox activity in the $0-2.2 \mathrm{~V}$ potential window (Fig. S14 $\dagger$ ), indicating that the coordinated PYA pincer ligands are redox inactive within this range. Likewise, the three pyridinium salt ligand precursors 1a-c do not show any oxidation process up to $2 \mathrm{~V}$ and feature an irreversible reduction processes around $-1 \mathrm{~V}$ (Fig. $\mathrm{S} 13 \dagger)$. This reduction is dependent on the PYA substitution pattern and easiest for ortho-PYA system $1 \mathrm{c}\left(E_{\mathrm{pc}}=-0.98 \mathrm{~V}\right)$, intermediate for meta-PYA $1 \mathbf{b}\left(E_{\mathrm{pc}}=-1.22 \mathrm{~V}\right)$ and at lowest potential for the para analogue $1 \mathrm{a}\left(E_{\mathrm{pc}}=-1.33 \mathrm{~V}\right)$.

Electrochemical characterization of the nickel complexes supports the trend in donor strength of the PYA pincer ligands as observed for the Co series. Thus, the $\mathrm{Ni}^{3+}$ oxidation state was stabilized better by the meta-PYA pincer ligand $\left(E_{1 / 2}=1.03\right.$ $\mathrm{V}$ in $3 \mathbf{b})$ than the para analogue $\left(E_{1 / 2}=1.20 \mathrm{~V}\right.$ in $\left.3 \mathbf{a}\right)$ or the ortho-pyPYA $\mathrm{A}_{2}$ system $\left(E_{1 / 2}=1.34 \mathrm{~V}\right.$ in $3 \mathrm{c}$; Fig. $\left.6 \mathrm{a}-\mathrm{c}\right)$. In addition, the stronger donor sets also provided access to $\mathrm{Ni}^{\mathrm{IV}}$ complexes via a second reversible oxidation at higher potential $\left(E_{1 / 2}=\right.$ $1.72 \mathrm{~V}$ and $1.54 \mathrm{~V}$ for complexes $\mathbf{3 a}$ and $\mathbf{3 b}$, respectively). Notably, $\left[\mathrm{Ni}(\text { terpy })_{2}\right]\left(\mathrm{PF}_{6}\right)_{2}$ as reference compound is oxidized at considerably higher potential $\left(E_{1 / 2}=1.65 \mathrm{~V}\right),{ }^{55}$ suggesting weaker donation of the terpy ligand than even the least basic ortho-pyPYA 2 ligand.

\section{H/D exchange in meta-PYA sites}

A closer investigation of the homoleptic cobalt complex $\mathbf{2 b}$ with meta-PYA pincer ligands revealed intriguing ligand-based reactivity. Crystallization of this complex in $\mathrm{D}_{2} \mathrm{O}$ under aerobic conditions resulted in a mixture of orange and green crystals. The latter are a product of spontaneous oxidation of a the metal center and furthermore revealed selective deuterium incorporation into the PYA heterocycle, as demonstrated by MS and NMR analyses. Material crystallized from $\mathrm{D}_{2} \mathrm{O}$ showed the $m / z$ signals for the mono-, di-, and tri-cationic species at 8 , 4 and 2.66 amu higher, respectively, than samples of $2 \mathbf{b}^{+}$crystallized from $\mathrm{H}_{2} \mathrm{O}$ (Table $\mathrm{S} 3 \dagger$ ). Formation of $\mathbf{2} \mathbf{b}^{+}-\boldsymbol{d}_{\mathbf{8}}$ was further supported by the absence of the PYA resonances at $\delta_{\mathrm{H}} 8.11$ and 8.25 in the ${ }^{1} \mathrm{H}$ NMR spectrum of the complex generated in $\mathrm{D}_{2} \mathrm{O}$ (Fig. S15 $\dagger$ ). Based on NOE spectroscopy as well as the pertinent coupling constants, these resonances were assigned to $\mathrm{H}_{\text {PYA }}^{2}$ and $\mathrm{H}_{\text {PYA }}^{6}$, respectively, i.e. the positions ortho to the PYA nitrogen. These data indicate a highly selective $H / D$ exchange. Interestingly, the isomeric complexes $\mathbf{2 a}$ and $2 \mathbf{c}$ containing para- and ortho-PYA pincer ligands, respectively do not undergo any detectable deuteration or oxidation (MS, NMR) when exposed to $\mathrm{D}_{2} \mathrm{O}$, presumably because of the higher oxidation potential of these complexes (vide supra). The selective deuterium incorporation in the PYA 2- and 6-position of $\mathbf{2 b}$ may be rationalized by considering resonance forms $\mathbf{B}$ and $\mathbf{C}$ of the meta-PYA ligand system, which imply a formally neutral imine donor site and opposite charges within the pyridylidene 

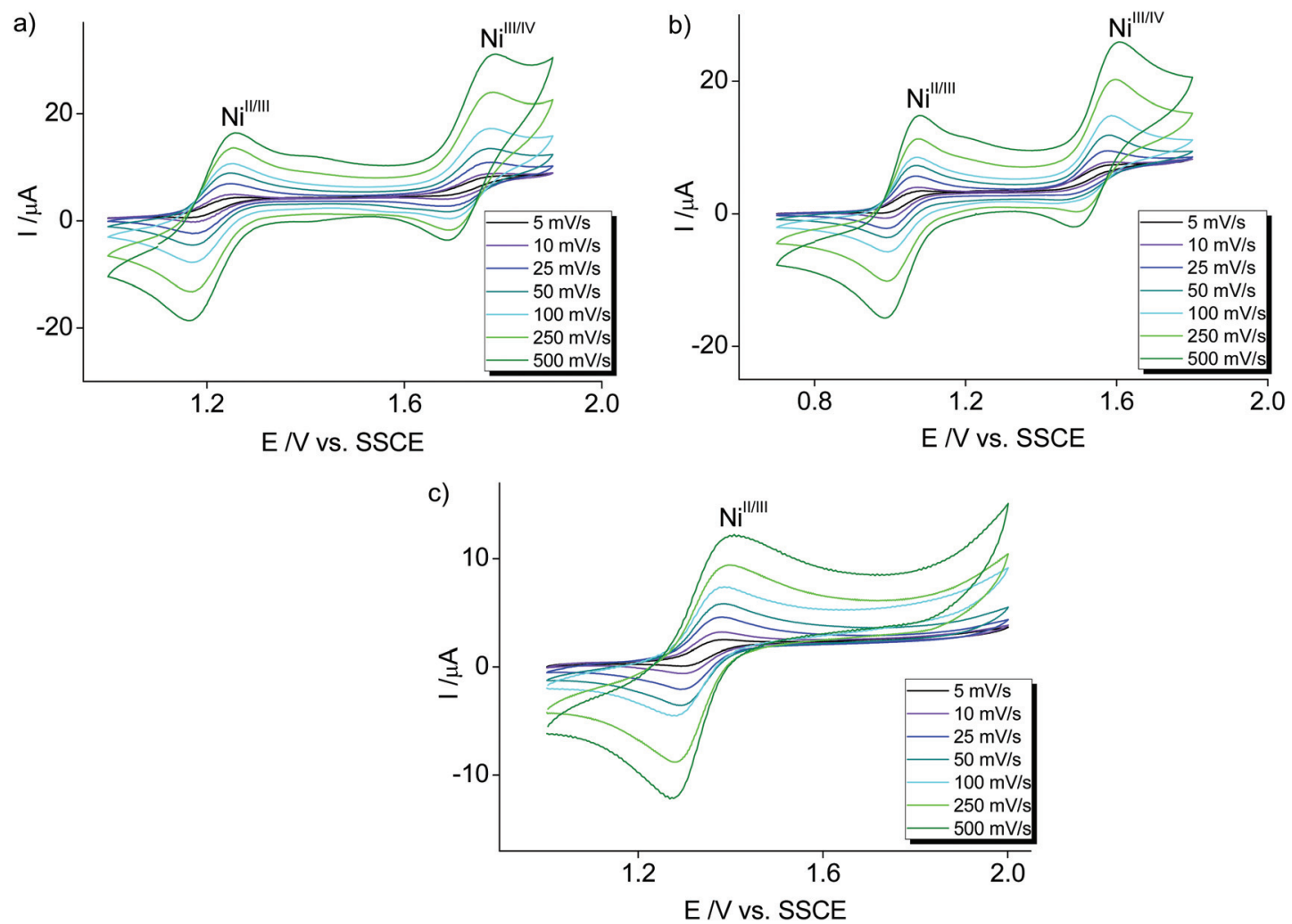

Fig. 6 Cyclic voltammetry measurements of homoleptic $\left[\mathrm{Ni}\left(\mathrm{pyPYA}_{2}\right)_{2}\right]\left(\mathrm{PF}_{6}\right)_{2}$ complexes in $\mathrm{MeCN}$ : (a) $3 a$ [Ni $\left.(\text { para-pyPYA })_{2}\right]\left(\mathrm{PF}_{6}\right)_{2} ;(\mathrm{b}) 3 \mathrm{~b}[\mathrm{Ni}(\mathrm{meta}-$ pyPYA $\left.\left._{2}\right)_{2}\right]\left(\mathrm{PF}_{6}\right)_{2} ;$ (c) $3 c$ [Ni(ortho-pyPYA $\left.\left.)_{2}\right)_{2}\right]\left(\mathrm{PF}_{6}\right)_{2}$. Conditions: $10 \mathrm{~mL}$ solvent, $1 \mathrm{mM}$ sample and $100 \mathrm{mM}\left(n \mathrm{Bu}_{4} \mathrm{~N}\right) \mathrm{PF}_{6}$ as supporting electrolyte at $5-500 \mathrm{mV} \mathrm{s}^{-1}$ scan rate (potentials vs. SSCE using the $\mathrm{Fc}^{+} / \mathrm{Fc}$ couple as standard; $E_{1 / 2}=+0.4319$ ).

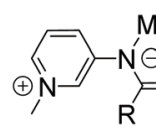

A
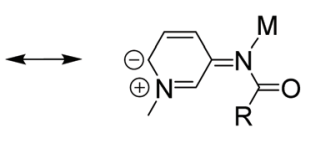

B

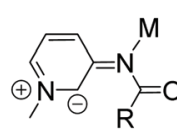

C

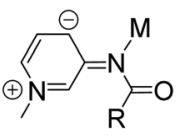

D

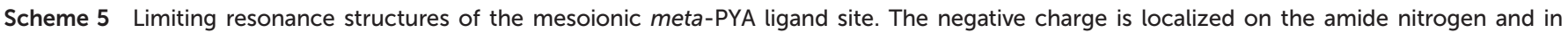
2-, 4- and 6-position of the PYA heterocycle.

heterocycle (Scheme 5). Reversible deuteration/protonation at the partially negatively charged positions would account for the observed selectivity and indicates that resonance forms $\mathbf{B}$ and $\mathbf{C}$ are contributing in addition to resonane form A. This contribution of several resonance structures therefore validates meta-PYA systems as mesoionic compounds. ${ }^{56}$

\section{Conclusions}

Here, we have shown that PYA pincer ligands form stable complexes with nickel, cobalt and zinc, which expands the application potential of this ligand beyond platinum group metals to first row metals. The substitution pattern of the PYA heterocycle influences the binding mode of the pincer ligand to these Earthabundant transition metals. meta- and para-pyPYA 2 ligand systems are exclusively $\kappa^{3}-N, N, N$-coordinated, whereas the orthomethylated PYA pincer ligand forms either $\kappa^{3}-O, N, O$-coordinated
mono-pyPYA $\mathrm{A}_{2}$ compounds or bis-pyPYA 2 complexes with a mixed $\kappa^{3}-O, N, O / \kappa^{3}-N, N, N$ coordination mode. According to electrochemical analyses, the donor strength of the PYA ligand systems decrease in the order meta-PYA > para-PYA > ortho-PYA. The mesoionic meta-PYA pincer cobalt complex displays unique reactivity, since the 2- and 6-positions of the pyridinium heterocycle are selectively deuterated in $\mathrm{D}_{2} \mathrm{O}$ under mild conditions. This deuteration suggests partial delocalization of the negative charge and therefore mesoionic properties of the meta-PYA unit. Moreover, this reactivity may become potentially useful for metal-ligand cooperative HX bond activation catalysis.

\section{Experimental}

\section{General}

All reagents were commercially available and used as received. Ligands $\mathbf{1 a}$ and $\mathbf{1 b}$ have been prepared according to previously 
described methods. ${ }^{19}$ Unless specified otherwise, ${ }^{1} \mathrm{H}$ NMR spectra were recorded at $25{ }^{\circ} \mathrm{C}$ on Bruker spectrometers operating at $300 \mathrm{MHz}$. Chemical shifts ( $\delta$ in ppm, coupling constants $J$ in $\mathrm{Hz}$ ) were referenced to residual solvent signals. Assignments are based on homo- and heteronuclear shift correlation spectroscopy. Purity of bulk samples of the complexes has been established by NMR spectroscopy, and when possible by elemental analysis. Elemental analyses were performed at DCB Microanalytic Laboratory using a Thermo Scientific Flash 2000 CHNS-O elemental analyzer. High-resolution ESI mass spectrometry was carried out with a Thermo Scientific LTQ Orbitrap XL (ESI-TOF). Cyclic voltammograms were recorded using an Autolab PGSTAT101 from Metrohm in MeCN solutions: $10 \mathrm{~mL}$ solvent, $1 \mathrm{mM}$ sample and $100 \mathrm{mM}$ tetrabutylammonium hexafluorophosphate $\left(n \mathrm{Bu}_{4} \mathrm{~N}\right) \mathrm{PF}_{6}$ as supporting electrolyte. Solutions were deaerated with argon gas for $10 \mathrm{~min}$ prior to each run. The scan rate was $100 \mathrm{mV} \mathrm{s}^{-1}$. Redox potentials were measured using a Pt-button working electrode, an $\mathrm{Ag} / \mathrm{AgCl}$ reference electrode and a Pt-wire auxiliary electrode and are tabulated versus a ferrocene internal standard. The $\mathrm{Fc}^{+} / \mathrm{Fc}$ couple is $0.43 \mathrm{~V} v$ s. $\mathrm{Ag} / \mathrm{AgCl}$ in $0.1 \mathrm{M}\left(n \mathrm{Bu}_{4} \mathrm{~N}\right) \mathrm{PF}_{6} \mathrm{MeCN}$ solutions. ${ }^{57}$ ATR-FTIR spectra were recorded with a Jasco FT/ IR-4700 spectrometer with a Jasco ATR Pro One unit containing a diamond crystal.

\section{Synthetic procedures}

Compound 1c. The bis-amide $N^{2}, N^{6}$-bis( pyridin-2-yl)pyridine2,6-dicarboxamide has been prepared according to literature procedures. ${ }^{33}$ Methylation was carried out under nitrogen atmosphere in 1,2-dichloroethane $(50 \mathrm{~mL})$ at $80{ }^{\circ} \mathrm{C}$ under vigorous stirring for 3 days with 5 eq. MeOTf $(1.64 \mathrm{~g} ; 10 \mathrm{mmol})$ in respect to the bis-amide ( $640 \mathrm{mg} ; 2 \mathrm{mmol}$ ). The reaction was quenched with $\mathrm{MeOH}(5 \mathrm{~mL})$ and the product precipitated upon addition of $\mathrm{Et}_{2} \mathrm{O}(50 \mathrm{~mL})$. It was purified by filtration and repetitive washing with $\mathrm{Et}_{2} \mathrm{O}(3 \times 50 \mathrm{~mL})$, yielding the bis-methylated OTf ligand salt pre-1c $(1.03 \mathrm{~g} ; 79 \%$ yield). The final product was obtained after anion exchange to $\mathrm{PF}_{6}$, which was achieved upon addition of 4 eq. $\mathrm{NH}_{4} \mathrm{PF}_{6}(1.04 \mathrm{~g} ; 6.3 \mathrm{mmol})$ to a solution of pre1c $(1.03 \mathrm{~g} ; 1.6 \mathrm{mmol})$ in $30 \mathrm{~mL}$ of a warm $\left(70^{\circ}\right) \mathrm{MeCN} /$ water mixture $(1: 2)$. The product crystallized upon slow cooling to room temperature, was filtered and washed with small portions of cold water $(3 \times 20 \mathrm{~mL})$ and dried under vacuum. 1c was obtained as white crystalline material $(0.73 \mathrm{~g} ; 72 \%) .{ }^{1} \mathrm{H}$ NMR $\left(300 \mathrm{MHz}, \mathrm{MeCN}-d_{3}\right) \delta 10.45(\mathrm{~s}, 2 \mathrm{H}, \mathrm{NH}), 8.64-8.51(\mathrm{~m}, 6 \mathrm{H}$, $\left.\mathrm{H}_{\mathrm{PYA}}, \mathrm{H}_{\mathrm{pyr}}\right), 8.46-8.36\left(\mathrm{~m}, 3 \mathrm{H}, \mathrm{H}_{\mathrm{PYA}}, \mathrm{H}_{\mathrm{pyr}}\right), 7.87-7.79(\mathrm{~m}, 2 \mathrm{H}$, $\left.\mathrm{H}_{\mathrm{PYA}}\right), 4.29\left(\mathrm{~s}, 6 \mathrm{H}, \mathrm{N}-\mathrm{CH}_{3}\right) .{ }^{13} \mathrm{C} \mathrm{NMR}\left(75 \mathrm{MHz}, \mathrm{MeCN}-d_{3}\right) \delta 163.1$ (CO), $148.1\left(\mathrm{C}_{\mathrm{pyr}}\right), 148.0\left(\mathrm{C}_{\mathrm{PYA}}\right), 147.9\left(\mathrm{CH}_{\mathrm{PYA}}\right), 146.5\left(\mathrm{CH}_{\mathrm{PYA}}\right)$, $141.9\left(\mathrm{CH}_{\mathrm{pyr}}\right), 128.8\left(\mathrm{CH}_{\mathrm{pyr}}\right), 125.1\left(\mathrm{CH}_{\mathrm{PYA}}\right), 124.7\left(\mathrm{CH}_{\mathrm{PYA}}\right), 45.4$ $\left(\mathrm{N}^{-} \mathrm{CH}_{3}\right)$. HR ESI-MS: $m / z$ calculated for $\mathrm{C}_{19} \mathrm{H}_{19} \mathrm{O}_{2} \mathrm{~N}_{5} \mathrm{~F}_{6} \mathrm{P}[\mathrm{M}-$ $\left.\mathrm{PF}_{6}\right]^{+}=494.1151$; found: 494.12. Elemental analysis: anal. calculated for $\mathrm{C}_{19} \mathrm{H}_{19} \mathrm{~F}_{12} \mathrm{~N}_{5} \mathrm{O}_{2} \mathrm{P}_{2}$ : C: $35.70 ; \mathrm{H}: 3.00 ; \mathrm{N}: 10.95$. Found: C: $36.28 ; \mathrm{H}: 2.95 ; \mathrm{N}: 11.03$.

\section{General procedure for compounds 2/3a-c}

The respective amounts of the ligands 1a-c (150 mg, $0.235 \mathrm{mmol}, 1$ eq.), $\mathrm{Na}_{2} \mathrm{CO}_{3}$ ( $75 \mathrm{mg}, 0.705 \mathrm{mmol}, 3$ eq.) and the $\mathrm{MCl}_{2} \cdot 6 \mathrm{H}_{2} \mathrm{O}$ salts $(28 \mathrm{mg}, 0.117 \mathrm{mmol}, 0.5 \mathrm{eq}$.) were dissolved in a $\mathrm{H}_{2} \mathrm{O} / \mathrm{EtOH}(1: 1)$ mixture $(10 \mathrm{~mL})$ and stirred at r.t. for $30 \mathrm{~min}$. The solvents were evaporated under reduced pressure. The crude product was redissolved in MeCN, cooled down to $-18{ }^{\circ} \mathrm{C}$ and filtered over a pad of Celite to remove sodium salt residues. The final products were obtained upon precipitation/crystallization from $\mathrm{Et}_{2} \mathrm{O}$.

Compound 2a: $\left[\mathrm{Co}(\text { para-PYA })_{2}\right]\left(\mathrm{PF}_{6}\right)_{2}$. According to general procedure starting from $1 \mathrm{a}$ and $\mathrm{CoCl}_{2} \cdot 6 \mathrm{H}_{2} \mathrm{O}$, which afforded $2 \mathrm{a}$ as light orange solid $(80 \mathrm{mg}, 66 \%)$. ESI-MS: $\mathrm{m} / \mathrm{z}$ calculated for $\left[\mathrm{M}-\mathrm{PF}_{6}\right]^{+}=898.1733$; found: 898.1733. Elemental analysis: anal. calculated for $\mathrm{C}_{38} \mathrm{H}_{34} \mathrm{CoF}_{12} \mathrm{~N}_{10} \mathrm{O}_{4} \mathrm{P}_{2}$ : C: 43.73; H: 3.28; N: 13.42. Found: C: $43.50 ; \mathrm{H}: 3.03 ; \mathrm{N}: 13.85$.

Compound 2b: $\left[\mathrm{Co}(\text { meta-PYA })_{2}\right]\left(\mathrm{PF}_{6}\right)_{2}$. According to general procedure starting from $\mathbf{1 b}$ and $\mathrm{CoCl}_{2} \cdot 6 \mathrm{H}_{2} \mathrm{O}$, which afforded 2b as orange solid $(120 \mathrm{mg}, 98 \%)$. ESI-MS: $\mathrm{m} / \mathrm{z}$ calculated for $\left[\mathrm{M}-\mathrm{PF}_{6}\right]^{+}=898.1733$; found: 898.1738. Elemental analysis: anal. calculated for $\mathrm{C}_{38} \mathrm{H}_{34} \mathrm{CoF}_{12} \mathrm{~N}_{10} \mathrm{O}_{4} \mathrm{P}_{2} \cdot \mathrm{H}_{2} \mathrm{O}$ : C: 42.99; $\mathrm{H}$ : 3.42; N: 13.19. Found: C: 43.05; H: 4.20; N: 13.44.

Compound $2 \mathbf{b}^{+}$: $\left[\mathrm{Co}(\text { meta-PYA })_{2}\right]\left(\mathbf{P F}_{6}\right)_{3}$. A saturated solution of complex $2 \mathbf{b}$ in $\mathrm{H}_{2} \mathrm{O}$ or $\mathrm{D}_{2} \mathrm{O}$ was left standing for 3 days which resulted in the formation of green crystals. The solvent was removed and the crystals washed with cold water and $\mathrm{Et}_{2} \mathrm{O}$ and dried in air to give $2 \mathbf{b}^{+}$(in $\mathrm{H}_{2} \mathrm{O}$ ) or $\mathbf{2} \mathbf{b}^{+}-\boldsymbol{d}_{\mathbf{8}}$ (in $\mathrm{D}_{2} \mathrm{O}$ ).

$2 \mathbf{b}^{+}$: ESI-MS: $m / z$ calculated for $\left[\mathrm{M}-\mathrm{PF}_{6}\right]^{+}=1043.1375$; found: $1043.1393 .{ }^{1} \mathrm{H}$ NMR $\left(300 \mathrm{MHz}, \mathrm{MeCN}-d_{3}\right): \delta 8.39\left(\mathrm{t},{ }^{3} J_{\mathrm{HH}}\right.$ $\left.=7.7 \mathrm{~Hz}, 2 \mathrm{H}, \mathrm{H}_{\mathrm{pyr}}\right), 8.27-8.22\left(\mathrm{~m}, 4 \mathrm{H}, \mathrm{H}_{\mathrm{PYA}}^{6}\right), 8.15\left(\mathrm{~d},{ }^{3} J_{\mathrm{HH}}=\right.$ $\left.7.7 \mathrm{~Hz}, 4 \mathrm{H}, \mathrm{H}_{\mathrm{pyr}}\right), 8.11\left(\mathrm{~s}, 4 \mathrm{H}, \mathrm{H}^{2}{ }_{\mathrm{PYA}}\right), 7.62-7.56(\mathrm{~m}, 8 \mathrm{H}$, $\left.\mathrm{H}^{4 / 5}{ }_{\mathrm{PYA}}\right), 4.09\left(\mathrm{~s}, 12 \mathrm{H}, \mathrm{N}^{-\mathrm{CH}_{3}}\right) \mathrm{ppm}$.

$2 \mathbf{b}^{+}-\boldsymbol{d}_{\mathbf{8}}$ : ESI-MS: $m / z$ calculated for $\left[\mathrm{M}-\mathrm{PF}_{6}\right]^{+}=1051.1877$; found: $1051.1883 .{ }^{1} \mathrm{H}$ NMR $\left(300 \mathrm{MHz}, \mathrm{MeCN}-d_{3}\right): \delta 8.39\left(\mathrm{t},{ }^{3} J_{\mathrm{HH}}\right.$ $\left.=7.7 \mathrm{~Hz}, 2 \mathrm{H}, \mathrm{H}_{\mathrm{pyr}}\right), 8.15\left(\mathrm{~d},{ }^{3} J_{\mathrm{HH}}=7.7 \mathrm{~Hz}, 4 \mathrm{H}, \mathrm{H}_{\mathrm{pyr}}\right), 7.61-7.56$ $\left(\mathrm{m}, 8 \mathrm{H}, \mathrm{H}^{4 / 5}{ }_{\text {PYA }}\right), 4.10\left(\mathrm{~s}, 12 \mathrm{H}, \mathrm{N}-\mathrm{CH}_{3}\right) \mathrm{ppm}$.

Compound 2c: $\left[\mathrm{Co}(\text { ortho-PYA })_{2}\right]\left(\mathrm{PF}_{6}\right)_{2}$. According to general procedure starting from $1 \mathrm{c}$ and $\mathrm{CoCl}_{2} \cdot 6 \mathrm{H}_{2} \mathrm{O}$, which afforded $2 \mathrm{c}$ as red solid (115 mg, 94\%). ESI-MS: $\mathrm{m} / z$ calculated for [M $\left.\mathrm{PF}_{6}\right]^{+}=$898.1733; found: 898.1724. Elemental analysis: anal. calculated for $\mathrm{C}_{38} \mathrm{H}_{34} \mathrm{CoF}_{12} \mathrm{~N}_{10} \mathrm{O}_{4} \mathrm{P}_{2}$ : C: $43.73 ; \mathrm{H}: 3.28 ; \mathrm{N}: 13.42$. Found: C: $42.22 ; \mathrm{H}: 2.57$; N: 13.51. Despite several attempts, no better microanalytical data were obtained. The irregular values may be associated with partial oxidation of the compound.

Compound 3a: [Ni(para-PYA $\left.)_{2}\right]\left(\mathbf{P F}_{6}\right)_{2}$. According to general procedure starting from $1 \mathrm{a}$ and $\mathrm{NiCl}_{2} \cdot 6 \mathrm{H}_{2} \mathrm{O}$, which afforded 3a as bright yellow solid (78 mg, 64\%). ESI-MS: $\mathrm{m} / \mathrm{z}$ calculated for $\left[\mathrm{M}-\mathrm{PF}_{6}\right]^{+}=897.1754$; found: 897.1730. Elemental analysis: anal. calculated for $\mathrm{C}_{38} \mathrm{H}_{34} \mathrm{NiF}_{12} \mathrm{~N}_{10} \mathrm{O}_{4} \mathrm{P}_{2} \cdot 0.5 \mathrm{H}_{2} \mathrm{O} \cdot 0.5 \mathrm{MeCN}$ : C: 43.66; H: 3.43; N: 13.71. Found: C: 43.40; H: 3.03; N: 14.15.

Compound 3b: $\left[\mathrm{Ni}(\text { meta-PYA })_{2}\right]\left(\mathrm{PF}_{6}\right)_{2}$. According to general procedure starting from $\mathbf{1 b}$ and $\mathrm{NiCl}_{2} \cdot 6 \mathrm{H}_{2} \mathrm{O}$, which afforded $\mathbf{3 b}$ as dark yellow solid (115 mg, 95\%). ESI-MS: $\mathrm{m} / \mathrm{z}$ calculated for $\left[\mathrm{M}-\mathrm{PF}_{6}\right]^{+}=897.1754$; found: 897.1758. Elemental analysis: anal. calculated for $\mathrm{C}_{38} \mathrm{H}_{34} \mathrm{NiF}_{12} \mathrm{~N}_{10} \mathrm{O}_{4} \mathrm{P}_{2} \cdot 1.5 \mathrm{H}_{2} \mathrm{O}$ : C: $42.64 ; \mathrm{H}$ : 3.48; N: 13.09. Found: C: 42.61; H: 4.09; N: 13.35 .

Compound 3c: [Ni(ortho-PYA $\left.)_{2}\right]\left(\mathrm{PF}_{6}\right)_{2}$. According to general procedure starting from $1 \mathrm{c}$ and $\mathrm{NiCl}_{2} \cdot 6 \mathrm{H}_{2} \mathrm{O}$, which afforded $3 \mathrm{c}$ as yellow/green solid $(75 \mathrm{mg}, 61 \%)$. ESI-MS: $\mathrm{m} / \mathrm{z}$ calculated for 
$\left[\mathrm{M}-\mathrm{PF}_{6}\right]^{+}=$897.1754; found: 897.1737. Elemental analysis: anal. calculated for $\mathrm{C}_{38} \mathrm{H}_{34} \mathrm{NiF}_{12} \mathrm{~N}_{10} \mathrm{O}_{4} \mathrm{P}_{2} \cdot \mathrm{H}_{2} \mathrm{O} \cdot \mathrm{MeCN}$ : C: 43.58; $\mathrm{H}: 3.57$; N: 13.98. Found: C: 43.14; H: 3.09; N: 14.04 .

\section{General procedure for compounds $4 / 5 a-c$}

The respective amounts of the ligands 1a-c (102 mg, $0.16 \mathrm{mmol}, 1$ eq.) and $\mathrm{Na}_{2} \mathrm{CO}_{3}$ (45 mg, $0.42 \mathrm{mmol}, 3$ eq.) were dissolved in DMF (4 mL) and stirred for $20 \mathrm{~min}$ at r.t. In a second vial the $\mathrm{MCl}_{2} \cdot 6 \mathrm{H}_{2} \mathrm{O}$ salts (38 mg, $0.16 \mathrm{mmol}, 1$ eq.) were dissolved in DMF ( $4 \mathrm{~mL})$. The ligand solution was filtered and slowly added to the metal solution. The combined reaction phase was stirred for another $2 \mathrm{~h}$ at r.t. and the final products were obtained upon precipitation/crystallization from $\mathrm{Et}_{2} \mathrm{O}$ and $\mathrm{MeCN} / \mathrm{Et}_{2} \mathrm{O}$.

Compound 4a: [Co(para-PYA $\left.) \mathrm{Cl}_{2}\right]$. According to general procedure starting from $1 \mathrm{a}$ and $\mathrm{CoCl}_{2} \cdot 6 \mathrm{H}_{2} \mathrm{O}$, which afforded $\mathbf{4 a}$ as light green solid (33 mg, 43\%). ESI-MS: $m / z$ calculated for [M $\mathrm{Cl}]^{+}=441.0403$; found: 441.0409. Elemental analysis: anal. calculated for $\mathrm{C}_{19} \mathrm{H}_{17} \mathrm{Cl}_{2} \mathrm{CoN}_{5} \mathrm{O}_{2}$ : C: $47.82 ; \mathrm{H}: 3.59 ; \mathrm{N}: 14.68$. Found: C: 47.91; H: 3.31; N: 15.04.

Compound 4b: [Co(meta-PYA) $\mathrm{Cl}_{2}$ ]. According to general procedure starting from $\mathbf{1 b}$ and $\mathrm{CoCl}_{2} \cdot 6 \mathrm{H}_{2} \mathrm{O}$, which afforded $\mathbf{4 b}$ as turquoise solid (35 mg, 46\%). ESI-MS: $\mathrm{m} / \mathrm{z}$ calculated for $[\mathrm{M}-$ $\mathrm{Cl}]^{+}=441.0403$; found: 441.0407 . Elemental analysis: anal. calculated for $\mathrm{C}_{19} \mathrm{H}_{17} \mathrm{Cl}_{2} \mathrm{CoN}_{5} \mathrm{O}_{2} \cdot 0.5 \mathrm{MeCN}$ : C: 48.26; $\mathrm{H}: 3.74 ; \mathrm{N}$ : 15.48. Found: C: $48.21 ; \mathrm{H}: 3.36$; N: 15.30 .

Compound 4c: [Co(ortho-PYA $\left.) \mathrm{Cl}_{2}\right]$. According to general procedure starting from $1 \mathrm{c}$ and $\mathrm{CoCl}_{2} \cdot 6 \mathrm{H}_{2} \mathrm{O}$, which afforded $4 \mathrm{c}$ as forest green solid (43 mg, 56\%). ESI-MS: $\mathrm{m} / \mathrm{z}$ calculated for $[\mathrm{M}-\mathrm{Cl}]^{+}=441.0403$; found: 441.0406. Elemental analysis: anal. calculated for $\mathrm{C}_{19} \mathrm{H}_{17} \mathrm{Cl}_{2} \mathrm{CoN}_{5} \mathrm{O}_{2}$ : C: $47.82 ; \mathrm{H}: 3.59 ; \mathrm{N}$ : 14.68. Found: C: $47.85 ; \mathrm{H}: 3.55 ; \mathrm{N}: 14.76$.

Compound 5a: [Ni(para-PYA $) \mathrm{Cl}_{2}$ ]. According to general procedure starting from $\mathbf{1 a}$ and $\mathrm{NiCl}_{2} \cdot 6 \mathrm{H}_{2} \mathrm{O}$, which afforded $\mathbf{5 a}$ as yellow/orange solid (31 mg, 41\%). ESI-MS: $\mathrm{m} / \mathrm{z}$ calculated for $[\mathrm{M}-\mathrm{Cl}]^{+}=440.0424$; found: 440.0410. Elemental analysis: anal. calculated for $\mathrm{C}_{19} \mathrm{H}_{17} \mathrm{Cl}_{2} \mathrm{NiN}_{5} \mathrm{O}_{2} \cdot 0.5 \mathrm{H}_{2} \mathrm{O}$ : C: $46.96 ; \mathrm{H}$ : 3.73; N: 14.41. Found: C: 47.29; H: 4.13; N: 14.75 .

Compound 5b: [Ni(meta-PYA $\left.) \mathrm{Cl}_{2}\right]$. According to general procedure starting from $\mathbf{1 b}$ and $\mathrm{NiCl}_{2} \cdot 6 \mathrm{H}_{2} \mathrm{O}$, which afforded $\mathbf{5 b}$ as yellow solid (39 mg, 51\%). ESI-MS: $\mathrm{m} / \mathrm{z}$ calculated for $[\mathrm{M}-\mathrm{Cl}]^{+}$ $=440.0424$; found: 440.0407. Elemental analysis: anal. calculated for $\mathrm{C}_{19} \mathrm{H}_{17} \mathrm{Cl}_{2} \mathrm{NiN}_{5} \mathrm{O}_{2}$ : C: $47.85 ; \mathrm{H}: 3.59 ; \mathrm{N}$ : 14.68. Found: $\mathrm{C}: 47.68 ; \mathrm{H}: 3.70 ; \mathrm{N}: 14.41$.

Compound 5c: [Ni(ortho-PYA $\left.) \mathrm{Cl}_{2}\right]$. According to general procedure starting from $1 \mathrm{c}$ and $\mathrm{NiCl}_{2} \cdot 6 \mathrm{H}_{2} \mathrm{O}$, which afforded $\mathbf{5 c}$ as green solid (42 mg, 55\%). ESI-MS: $m / z$ calculated for $[\mathrm{M}-\mathrm{Cl}]^{+}$ $=440.0424$; found: 440.0410. Elemental analysis: anal. calculated for $\mathrm{C}_{19} \mathrm{H}_{17} \mathrm{Cl}_{2} \mathrm{NiN}_{5} \mathrm{O}_{2}$ : C: $47.85 ; \mathrm{H}: 3.59 ; \mathrm{N}$ : 14.68 . Found: C: $47.72 ; \mathrm{H}: 3.73 ; \mathrm{N}: 14.31$.

\section{General procedure for compounds $6 \mathrm{a}-\mathrm{c}$}

The respective amounts of ligands $1 \mathrm{a}-\mathrm{c}(100 \mathrm{mg}, 0.16 \mathrm{mmol}$, 1 eq.) were reacted with $\mathrm{Na}_{2} \mathrm{CO}_{3}$ (85 mg, 0.80 mmol, 5 eq.) in $\operatorname{MeCN}(5 \mathrm{~mL}$ ) for $1 \mathrm{~h}$ at room temperature in a vial. Then a 0.2 $\mathrm{M} \mathrm{ZnCl}_{2}$ solution in $\mathrm{MeCN}(470 \mu \mathrm{L}, 0.09 \mathrm{mmol}, 0.55$ eq.) was added to the ligand solution. The vial was sealed and heated up to $50{ }^{\circ} \mathrm{C}$ for $16 \mathrm{~h}$ under constant stirring. The reaction mixture was cooled to r.t. and filtered through Celite. A white solid was precipitated from $\mathrm{Et}_{2} \mathrm{O}(20 \mathrm{~mL})$. The solid was collected by filtration over a fritted funnel, rinsed with $\mathrm{Et}_{2} \mathrm{O}$ $(3 \times 5 \mathrm{~mL})$ and dried.

Compound 6a: $\left[\mathrm{Zn}(\text { para-PYA })_{2}\right]\left(\mathbf{P F}_{6}\right)_{2}$. According to general procedure starting from 1a and giving complex 6a as a white solid (47 mg, 54\% yield). ${ }^{1} \mathrm{H}$ NMR (300 MHz, MeCN- $d_{3}$ ): $\delta$ 8.47-8.24 (m, 3H, $\mathrm{H}_{\text {Pyr }}$ ), 7.77 (d, $\left.{ }^{3} \mathrm{~J}_{\mathrm{HH}}=7.3 \mathrm{~Hz}, 4 \mathrm{H}, \mathrm{H}_{\mathrm{PYA}}\right), 7.22$ $\left(\mathrm{d},{ }^{3} \mathrm{~J}_{\mathrm{HH}}=7.3 \mathrm{~Hz}, 4 \mathrm{H}, \mathrm{H}_{\mathrm{PYA}}\right), 3.88\left(\mathrm{~s}, 6 \mathrm{H}, \mathrm{N}-\mathrm{CH}_{3}\right) \mathrm{ppm} .{ }^{13} \mathrm{C} \mathrm{NMR}$ (75 MHz, MeCN- $d_{3}$ ): $\delta 166.73(\mathrm{CO}), 165.14\left(\mathrm{C}_{\mathrm{PYA}}\right), 149.89\left(\mathrm{C}_{\mathrm{Pyr}}\right)$, $143.73\left(\mathrm{CH}_{\text {PYA }}\right), 143.35\left(\mathrm{CH}_{\text {Pyr }}\right), 125.90\left(\mathrm{CH}_{\text {Pyr }}\right), 120.89\left(\mathrm{CH}_{\text {PYA }}\right)$, $46.13\left(\mathrm{~N}^{-\mathrm{CH}_{3}}\right)$ ppm. ESI-MS: $m / z$ calculated for $\left[\mathrm{M}-\mathrm{PF}_{6}\right]^{+}$ 903.1698; found: 903.1674. Elemental analysis: anal. calculated for $\mathrm{C}_{38} \mathrm{H}_{34} \mathrm{~F}_{12} \mathrm{~N}_{10} \mathrm{O}_{4} \mathrm{P}_{2} \mathrm{Zn} \cdot 2 \mathrm{H}_{2} \mathrm{O}$ : C: $42.02 ; \mathrm{H}: 3.53 ; \mathrm{N}: 12.90$. Found: C: 42.03 ; H: 3.18; N: 12.80 .

Compound 6b: $\left[\mathrm{Zn}(\text { meta-PYA })_{2}\right]\left(\mathbf{P F}_{6}\right)_{2}$. According to general procedure starting from $\mathbf{1 b}$ and giving complex $\mathbf{6 b}$ as a white solid (46 mg, 55\% yield). ${ }^{1} \mathrm{H}$ NMR (300 MHz, MeCN- $d_{3}$ ): $\delta 8.43$ (s, 2H, $\mathrm{H}_{\mathrm{PYA}}$ ), 8.29-8.18 (m, 3H, $\left.\mathrm{H}_{\mathrm{Pyr}}\right), 7.88\left(\mathrm{~d},{ }^{3} J_{\mathrm{HH}}=5.9 \mathrm{~Hz}\right.$, $2 \mathrm{H}, \mathrm{H}_{\text {PYA }}$ ), 7.77 (d, ${ }^{3} J_{\mathrm{HH}}=8.5 \mathrm{~Hz}, 2 \mathrm{H}, \mathrm{H}_{\mathrm{PYA}}$ ), $7.38\left(\mathrm{dd},{ }^{3} J_{\mathrm{HH}}=\right.$ 8.5, $\left.5.9 \mathrm{~Hz}, 2 \mathrm{H}, \mathrm{H}_{\mathrm{PYA}}\right), 3.97\left(\mathrm{~s}, 6 \mathrm{H}, \mathrm{N}-\mathrm{CH}_{3}\right) \mathrm{ppm} .{ }^{13} \mathrm{C} \mathrm{NMR}$ (75 MHz, MeCN- $\left.d_{3}\right): \delta 165.61$ (CO), $151.40\left(\mathrm{C}_{\mathrm{PYA}}\right), 150.59\left(\mathrm{C}_{\mathrm{Pyr}}\right)$, $143.43\left(\mathrm{CH}_{\text {Pyr }}\right), 140.48\left(\mathrm{CH}_{\text {PYA }}\right), 139.66\left(\mathrm{CH}_{\text {PYA }}\right), 137.10\left(\mathrm{CH}_{\mathrm{PYA}}\right)$, $127.66\left(\mathrm{CH}_{\mathrm{PYA}}\right), 124.93\left(\mathrm{CH}_{\mathrm{Pyr}}\right), 48.95\left(\mathrm{~N}-\mathrm{CH}_{3}\right)$ ppm. ESI-MS: $\mathrm{m} / \mathrm{z}$ calculated for $\left[\mathrm{M}-\mathrm{PF}_{6}\right]^{+}$903.1698; found: 903.1680 . Elemental analysis: anal. calculated for $\mathrm{C}_{38} \mathrm{H}_{34} \mathrm{~F}_{12} \mathrm{~N}_{10} \mathrm{O}_{4} \mathrm{P}_{2} \mathrm{Zn} \cdot 2 \mathrm{H}_{2} \mathrm{O}: \mathrm{C}: 42.02 ; \mathrm{H}: 3.53 ; \mathrm{N}: 12.90$. Found: $\mathrm{C}: 41.95 ; \mathrm{H}: 3.23 ; \mathrm{N}: 12.75$.

Compound 6c: $\left[\mathrm{Zn}(\text { ortho-PYA })_{2}\right]\left(\mathbf{P F}_{6}\right)_{2}$. According to general procedure starting from $1 \mathrm{c}$ and giving complex $\mathbf{6 c}$ as a white solid (72 mg, 80\% yield). ${ }^{1} \mathrm{H}$ NMR (300 MHz, MeCN- $\left.d_{3}\right): \delta 8.70$ $\left(\mathrm{d},{ }^{3} \mathrm{~J}_{\mathrm{HH}}=7.8 \mathrm{~Hz}, 2 \mathrm{H}, \mathrm{H}_{\mathrm{Pyr}}\right), 8.41\left(\mathrm{t},{ }^{3} J_{\mathrm{HH}}=7.8 \mathrm{~Hz}, 1 \mathrm{H}, \mathrm{H}_{\text {Pyr }}\right.$ ), $8.11\left(\mathrm{dd},{ }^{3 / 4} J_{\mathrm{HH}}=6.5,1.7 \mathrm{~Hz}, 2 \mathrm{H}, \mathrm{H}_{\mathrm{PYA}}\right), 8.06\left(\mathrm{~d},{ }^{3} J_{\mathrm{HH}}=8.7 \mathrm{~Hz}\right.$, $2 \mathrm{H}, \mathrm{H}_{\mathrm{PYA}}$ ), $7.85\left(\mathrm{dt},{ }^{3 / 4} J_{\mathrm{HH}}=7.9,1.7 \mathrm{~Hz}, 2 \mathrm{H}, \mathrm{H}_{\mathrm{PYA}}\right), 7.08$ (dt, $\left.{ }^{3} J_{\mathrm{HH}}=6.8,1.4 \mathrm{~Hz}, 2 \mathrm{H}, \mathrm{H}_{\mathrm{PYA}}\right), 4.02\left(\mathrm{~s}, 6 \mathrm{H}, \mathrm{N}-\mathrm{CH}_{3}\right) \mathrm{ppm} .{ }^{13} \mathrm{C}$ NMR (75 MHz, MeCN- $d_{3}$ ) $\delta 166.38$ (CO), 159.57 (C $\left.\mathrm{C}_{\mathrm{PYA}}\right), 150.23$ $\left(\mathrm{C}_{\text {Pyr }}\right), 144.20\left(\mathrm{CH}_{\text {PYA }}\right), 143.86\left(\mathrm{CH}_{\text {Pyr }}\right), 143.51\left(\mathrm{CH}_{\text {PYA }}\right), 127.03$ $\left(\mathrm{CH}_{\mathrm{Pyr}}\right), 122.96$ ( $\left.\mathrm{CH}_{\mathrm{PYA}}\right), 118.0\left(\mathrm{CH}_{\mathrm{PYA}}\right), 43.60\left(\mathrm{CH}_{3}\right) \mathrm{ppm}$. ESI-MS: $m / z$ calculated for $\left[\mathrm{M}-\mathrm{PF}_{6}\right]^{+}$903.1698; found: 903.1673. Elemental analysis: anal. calculated for $\mathrm{C}_{38} \mathrm{H}_{34} \mathrm{~F}_{12} \mathrm{~N}_{10} \mathrm{O}_{4} \mathrm{P}_{2} \mathrm{Zn}: \mathrm{C}: 43.47 ; \mathrm{H}: 3.26$; N: 13.34. Found: C: 42.99; H: 3.16; N: 13.11 .

\section{Crystal-structure determination}

Suitable single crystals of $\mathbf{2} \mathbf{b}-\mathbf{c}, 3 \mathbf{b}-\mathbf{c}$, and $\mathbf{4 a - c}$ were mounted in air at ambient conditions and measured on an Oxford Diffraction SuperNova area-detector diffractometer ${ }^{58}$ using mirror optics monochromated Mo K $\alpha$ radiation $(\lambda=0.71073 \AA)$ and Al filtered. ${ }^{59}$ The unit cell constants and an orientation matrix for data collection were obtained from a least-squares refinement of the setting angles of reflections. Data reduction was performed using the CrysAlisPro ${ }^{58}$ program. The intensities were corrected for Lorentz and polarization effects, and a numerical absorption correction based on Gaussian inte- 
gration over a multifaceted crystal model was applied. The structure was solved by direct methods using SHELXT, ${ }^{60}$ which revealed the positions of all non-hydrogen atoms of the title compounds. The non-hydrogen atoms were refined anisotropically. All H-atoms were placed in geometrically calculated positions and refined using a riding model where each $\mathrm{H}$-atom was assigned a fixed isotropic displacement parameter with a value equal to $1.2 U_{\text {eq }}$ of its parent atom $\left(1.5 U_{\text {eq }}\right.$ for methyl groups and water). Refinement of the structure was carried out on $F^{2}$ using full-matrix least-squares procedures, which minimized the function $\sum \mathrm{w}\left(F_{\mathrm{o}}{ }^{2}-{F_{\mathrm{c}}}^{2}\right)^{2}$. The weighting scheme was based on counting statistics and included a factor to downweight the intense reflections. All calculations were performed using the SHELXL-2014/7 ${ }^{61}$ program in OLEX2. ${ }^{62}$ The $\mathrm{PF}_{6}{ }^{-}$ anions in the crystals of complex $\mathbf{2 b}, \mathbf{2} \mathbf{c}$, and $\mathbf{3 b}$ are disordered as indicated by the high residual electron density peak near its P-atom. No conclusive disorder model was found for $\mathbf{2 b}$ and $\mathbf{3 b}$, while for $\mathbf{2 c}$, disorders about two sites were restrained by SHELX SIMU and RIGU instructions. Further details are given in Tables S4-S6. $\uparrow$ Crystallographic data for all structures have been deposited with the Cambridge Crystallographic Data Centre (CCDC) as supplementary publication numbers 2015875 (2b), 2015876 (2b $\left.^{+}\right), 2015877$ (2c), 2015878 (3b), 2015879 (3c), 2015880 (4a), 2015881 (4b), 2015882 (4c), and $2015883\left(\left[\mathrm{Ru}(\right.\right.$ ortho-pyPYA 2$\left.\left.)(\mathrm{MeCN})_{3}\right]\left(\mathrm{PF}_{6}\right)_{2}\right) \cdot \dagger$

\section{Conflicts of interest}

The authors declare no conflict of interest.

\section{Acknowledgements}

We acknowledge generous financial support from the European Research Council (CoG 615653) and from the Swiss National Science Foundation (200021_162868 and 200020_182663, R'equip projects 206021_128724 and 206021_170755). We thank the group of Chemical Crystallography of the University of Bern for the X-ray analysis of all reported structures.

\section{References}

1 F. Haber and G. van Oordt, Z. Anorg. Allg. Chem., 1905, 44, 341-378.

2 M. Appl, in Ullmann's Encyclopedia of Industrial Chemistry, Wiley-VCH, Weinheim, 2011.

3 Handbook of Heterogeneous Catalysis, ed. G. Ertl, H. Knözinger and J. Weitkamp, Wiley-VCH, Weinheim, 2nd edn, 2008.

4 G. F. Froment, J. Mol. Catal. A: Chem., 2000, 163, 147-156.

5 L. Wang, D. Li, M. Koike, H. Watanabe, Y. Xu, Y. Nakagawa and K. Tomishige, Fuel, 2013, 112, 654-661.

6 J. R. Rostrup-Nielsen, Catal. Today, 2000, 63, 159-164.
7 L. W. Covert and H. Adkins, J. Am. Chem. Soc., 1932, 54, 4116-4117.

8 H. Adkins and H. R. Billica, J. Am. Chem. Soc., 1948, 70, 695-698.

9 M. Albrecht and G. Van Koten, Angew. Chem., Int. Ed., 2001, 40, 3750-3781.

10 B. Su, Z. C. Cao and Z. J. Shi, Acc. Chem. Res., 2015, 48, 886-896.

11 H. C. Urey, Rev. Mod. Phys., 1952, 28, 53-74.

12 J. W. Morgan and E. Anders, Proc. Natl. Acad. Sci. U. S. A., 1969, 77, 6973-6977.

13 P. E. Brubaker, J. P. Moran, K. Bridbord and F. G. Hueter, Environ. Health Perspect., 1975, 10, 39-56.

14 L. Alig, M. Fritz and S. Schneider, Chem. Rev., 2019, 119, 2681-2751.

15 I. Bauer and H.-J. Knölker, Chem. Rev., 2015, 115, 31703387.

16 W. Zuo, A. J. Lough, Y. F. Li and R. H. Morris, Science, 2013, 342, 1080-1084.

17 M. Garbe, K. Junge and M. Beller, Eur. J. Org. Chem., 2017, 4344-4362.

18 S. Z. Tasker, E. A. Standley and T. F. Jamison, Nature, 2014, 509, 299-309.

19 P. Melle, Y. Manoharan and M. Albrecht, Inorg. Chem., 2018, 57, 11761-11774.

20 P. Melle, J. Thiede, D. A. Hey and M. Albrecht, Chem. - Eur. J., 2020, DOI: 10.1002/chem.202001145.

21 P. Melle and M. Albrecht, Chimia, 2019, 73, 299-303.

22 K. F. Donnelly, C. Segarra, L.-X. Shao, R. Suen, H. MüllerBunz and M. Albrecht, Organometallics, 2015, 34, 4076-4084.

23 V. Leigh, D. J. Carleton, J. Olguin, H. Mueller-Bunz, L. J. Wright and M. Albrecht, Inorg. Chem., 2014, 53, 80548060 .

24 K. Salzmann, C. Segarra and M. Albrecht, Angew. Chem., 2020, 59, 8932-8936.

25 A. Weilhard, K. Salzmann, M. Navarro, J. Dupont, M. Albrecht and V. Sans, J. Catal., 2020, 385, 1-9.

26 M. Navarro, C. Segarra, P. Tim and M. Albrecht, Organometallics, 2020, 39, 2383-2391.

27 M. Navarro, V. Rosar, T. Montini, B. Milani and M. Albrecht, Organometallics, 2018, 37, 3619-3630.

28 M. Navarro, M. Li, H. Müller-Bunz, S. Bernhard and M. Albrecht, Chem. - Eur. J., 2016, 22, 6740-6745.

29 M. Navarro, M. Li, S. Bernhard and M. Albrecht, Dalton Trans., 2017, 47, 659-662.

30 M. Navarro, C. A. Smith, M. Li, S. Bernhard and M. Albrecht, Chem. - Eur. J., 2018, 24, 6386-6398.

31 M. E. Doster and S. A. Johnson, Angew. Chem., Int. Ed., 2009, 48, 2185-2187.

32 Q. Shi, R. J. Thatcher, J. Slattery, P. S. Sauari, A. C. Whitwood, P. C. McGowan and R. E. Douthwaite, Chem. - Eur. J., 2009, 15, 11346-11360.

33 A. Dorazco-González, H. Höpfl, F. Medrano and A. K. Yatsimirsky, J. Org. Chem., 2010, 75, 2259-2273.

34 A. K. Patra and R. Mukherjee, Inorg. Chem., 1999, 38, 1388-1393. 
35 D. Huang and R. H. Holm, J. Am. Chem. Soc., 2010, 132, 4693-4701.

36 P. Pirovano, E. R. Farquhar, M. Swart and A. R. McDonald, J. Am. Chem. Soc., 2016, 138, 14362-14370.

37 C. M. A. Muller, M. V. Babak, M. Kubanik, M. Hanif, S. M. F. Jamieson, C. G. Hartinger and L. J. Wright, Inorg. Chim. Acta, 2016, 450, 124-130.

38 With iron and cobalt observed in pyridine dicarboxamide systems, see: (a) G. L. Guillet, J. B. Gordon, G. N. Di Francesco, M. W. Calkins, E. Čižmár, K. A. Abboud, M. W. Meisel, R. García-Serres and L. J. Murray, Inorg. Chem., 2015, 54, 2691-2704; (b) T. C. Harrop, L. A. Tyler, M. M. Olmstead and P. K. Mascharak, Eur. J. Inorg. Chem., 2003, 475-481.

39 P. Pirovano, B. Twamley and A. R. McDonald, Chem. - Eur. J., 2018, 24, 5238-5245.

40 A. W. Addison, T. N. Rao, J. Reedijk, J. van Rijn and G. C. Verschoor, J. Chem. Soc., Dalton Trans., 1984, 13491356.

41 E. Goldschmied and N. C. Stephenson, Acta Crystallogr., Sect. B: Struct. Crystallogr. Cryst. Chem., 1970, 26, 18671875.

42 X. Zhang, D. Huang, Y. S. Chen and R. H. Holm, Inorg. Chem., 2012, 51, 11017-11029.

43 D. Bansal, G. Kumar, G. Hundal and R. Gupta, Dalton Trans., 2014, 43, 14865-14875.

44 D. Bansal and R. Gupta, Dalton Trans., 2019, 48, 1473714747.

45 For examples of $\kappa^{3}-O, N, O$ coordination due to grid restrains, see: (a) L. K. Thompson, L. Zhao, Z. Xu, D. O. Miller and W. M. Reiff, Inorg. Chem., 2003, 42, 128139; (b) L. N. Dawe, K. V. Shuvaev and L. K. Thompson, Inorg. Chem., 2009, 48, 3323-3341.

46 H. Eyring, J. Chem. Phys., 1935, 3, 107-115.

47 The TC were obtained upon comparing ${ }^{1} \mathrm{H}$ NMR spectra of 6c recorded in $\mathrm{CD}_{2} \mathrm{Cl}_{2}$ in the +20 to $-80{ }^{\circ} \mathrm{C}$ temperature range. The difference of the resonance frequencies $(\delta \nu)$ was calculated from chemical shift differences for protons of the major species, i.e. bis-( $\kappa^{3}-N, N, N$-pincer $)$, to the average chemical shift of the corresponding protons in the minor species $\left(\kappa^{3}-N, N, N / \kappa^{3}-O, N, O\right.$-isomer $)$. The energy barrier $\left(\Delta G^{\ddagger}\right.$ ) between the two isomers was estimated by using the following equation: $\Delta G^{\ddagger}=4.57 \cdot T_{\mathrm{c}} \cdot\left(9.97+\log T_{\mathrm{c}} / \delta \nu\right)$ according to: H. Günther, NMR-Spektroskopie, Thieme, Stuttgart, 1973.

48 M. Hesse, H. Meier and B. Zeeh, Spektroskopische Methoden in der organischen Chemie, Thieme, Stuttgart, Germany, 8th edn, 2012.
49 C. M. Harris, T. N. Lockyer, R. L. Martin, R. L. Patil, E. Sinn and I. M. Stewart, Aust. J. Chem., 1969, 22, 2105-2126.

50 M. Navarro, Doctoral dissertation, University of Bern, 2017.

51 C. Arana, S. Yan, M. Keshavarz-K, K. T. Potts and H. D. Abruña, Inorg. Chem., 1992, 31, 3680-3682.

52 Ideal value one electron process is $56.5 \mathrm{mV}$ according to Butler-Volmer equation, experimental values are known to be slightly higher; T. Erdey-Grúz and M. Volmer, Z. Phys. Chem., 1930, 150, 203-213.

53 We note that the CV of complex $2 \mathbf{a}$ indicates a second oxidation process at slightly higher potential. This process might be rationalized by a linkage isomerism also in this compound, though we do not have any experimental support for dynamic $O$ - vs. $N$-coordination of para-pyPYA ligands.

54 J.-M. Savéant, Elements of Molecular and Biomolecular Electrochemistry, John Wiley \& Sons, Hoboken, United States, 2006.

55 A. J. Bard and L. R. Faulkner, Electrochemical Methods: Fundamentaland Applications, John Wiley \& Sons, Hoboken, United States, 2nd edn, 2001.

56 Mesoionic compounds are defined by IUPAC as "dipolar five- (possibly six-) membered heterocyclic compounds in which both the negative and the positive charge are delocalized, for which a totally covalent structure cannot be written, and which cannot be represented satisfactorily by any one polar structure. The formal positive charge is associated with the ring atoms, and the formal negative charge is associated with ring atoms or an exocyclic nitrogen or chalcogen atom". IUPAC. Compendium of Chemical Terminology, 2nd Ed. Gold Book Compiled by A. D. McNaught and A. Wilkinson, Blackwell Scientific Publications, Oxford, 1997. XML online corrected version: http://goldbook.iupac.org (2006) created by M. Nic, J. Jirat, and B. Kosata updates compiled by A. Jenkins. ISBN 09678550-9-8.

57 N. G. Connelly and W. E. Geiger, Chem. Rev., 1996, 96, 877910.

58 Oxford Diffraction Ltd., CrysAlisPro, Yarnton, Oxfordshire, U.K., Version 1., 2010.

59 P. Macchi, H.-B. Bürgi, A. S. Chimpri, J. Hauser and Z. Gál, J. Appl. Crystallogr., 2011, 44, 763-771.

60 G. M. Sheldrick, Acta Crystallogr., Sect. C: Struct. Chem., 2015, 71, 3-8.

61 G. M. Sheldrick, Acta Crystallogr., Sect. A: Found. Adv., 2015, 71, 3-8.

62 O. V. Dolomanov, L. J. Bourhis, R. J. Gildea, J. A. K. Howard and H. Puschmann, J. Appl. Crystallogr., 2009, 42, 339-341. 